\title{
Insights into Solar Disinfection Enhancements for Drinking Water Treatment Applications
}

\author{
Abdassalam A. Azamzam ${ }^{1}$, Mohd Rafatullah ${ }^{1, *}{ }^{\mathbb{D}}$, Esam Bashir Yahya ${ }^{1} \mathbb{1}$, Mardiana Idayu Ahmad ${ }^{1}{ }^{1}$, \\ Japareng Lalung ${ }^{1}\left(\mathbb{D}\right.$, Sarah Alharthi ${ }^{2}{ }^{-}$, Abeer Mohammad Alosaimi ${ }^{2}$ and Mahmoud A. Hussein $\left.{ }^{3,4}{ }^{(}\right)$ \\ 1 Division of Environmental Technology, School of Industrial Technology, Universiti Sains Malaysia, \\ Penang 11800, Malaysia; azamzamabdassalam@student.usm.my (A.A.A.); \\ esamyahya@student.usm.my (E.B.Y.); mardianaidayu@usm.my (M.I.A.); japareng@usm.my (J.L.) \\ 2 Department of Chemistry, Faculty of Science, Taif University, P.O. Box 11099, Taif 21944, Saudi Arabia; \\ sarah.alharthi@tu.edu.sa (S.A.); a.alosaimi@tu.edu.sa (A.M.A.) \\ 3 Chemistry Department, Faculty of Science, King Abdulaziz University, P.O. Box 80203, \\ Jeddah 21589, Saudi Arabia; maabdo@kau.edu.sa \\ 4 Chemistry Department, Faculty of Science, Assiut University, Assiut 71516, Egypt \\ * Correspondence: mrafatullah@usm.my; Tel.: +6-046-532-111; Fax: +6-046-56375
}

check for updates

Citation: Azamzam, A.A.; Rafatullah, M.; Yahya, E.B.; Ahmad, M.I.; Lalung, J.; Alharthi, S.; Alosaimi, A.M.; Hussein, M.A. Insights into Solar Disinfection Enhancements for Drinking Water Treatment Applications. Sustainability 2021, 13, 10570. https://doi.org/10.3390/ su131910570

Academic Editor: Agostina Chiavola

Received: 4 September 2021

Accepted: 20 September 2021

Published: 23 September 2021

Publisher's Note: MDPI stays neutral with regard to jurisdictional claims in published maps and institutional affiliations.

Copyright: (c) 2021 by the authors. Licensee MDPI, Basel, Switzerland. This article is an open access article distributed under the terms and conditions of the Creative Commons Attribution (CC BY) license (https:/ / creativecommons.org/licenses/by/ $4.0 /)$.

\begin{abstract}
Poor access to drinking water, sanitation, and hygiene has always been a major concern and a main challenge facing humanity even in the current century. A third of the global population lacks access to microbiologically safe drinking water, especially in rural and poor areas that lack proper treatment facilities. Solar water disinfection (SODIS) is widely proven by the World Health Organization as an accepted method for inactivating waterborne pathogens. A significant number of studies have recently been conducted regarding its effectiveness and how to overcome its limitations, by using water pretreatment steps either by physical, chemical, and biological factors or the integration of photocatalysis in SODIS processes. This review covers the role of solar disinfection in water treatment applications, going through different water treatment approaches including physical, chemical, and biological, and discusses the inactivation mechanisms of water pathogens including bacteria, viruses, and even protozoa and fungi. The review also addresses the latest advances in different pre-treatment modifications to enhance the treatment performance of the SODIS process in addition to the main limitations and challenges.
\end{abstract}

Keywords: water treatment; solar disinfection; pre-treatment; mechanism; SODIS system

\section{Introduction}

Access to safe drinking water is essential to health, which has been always a major concern as one of the basic human health fundamental rights worldwide. More than 2 billion people around the world lack proper sanitation and hygiene in terms of drinking water [1]. Treatment techniques for drinking water in many undeveloped and developing countries are either insufficient or inaccessible, and thus, millions lack access to safe water service. However, it has been reported that roughly 144 million mainly rely on surface water as their main source for drinking, cooking, and daily usage, resulting in half a million deaths annually, caused by diarrheal symptoms alone apart from other waterborne diseases [2]. In many urban areas, the governments supply households with clean water, after intensive treatment with a combination of traditional treatment techniques including chlorination, filtration, ultraviolet irradiation (UV irradiation), ozonation, flocculation, Fenton and photo-Fenton approach, etc. However, with the significant increase in world population, these methods may not adequately address the requirement of all households for drinking water, especially in the poor villages.

The past few years witnessed the development of many cost-effective and proper water treatment technologies, using sustainable and eco-friendly principals instead of 
chemical treatment processes [3]. Conventional SODIS has been used in many isolated regions in Africa and south-east Asia as a household water treatment method [3,4]. The utilization of solar power in water treatment has recently gained tremendous attention due to its accessibility, cost-effectiveness, and availability in most undeveloped countries. Despite the effectiveness and low costs of the most currently applied water treatment approaches such as ozonation, chlorination, and advanced oxidation processes they have major drawbacks including the generation of potential harmful byproducts, decomposition of organic pollutants, and/or inactivation instead of killing of water pathogenic microorganisms [5-8]. Different approaches have been used for solar disinfection, such as the filling of transparent polyethylene bottles with untreated water and then exposing them to sunlight for variable time, depending on the climate [9]. This simple procedure was found to be sufficient for killing the bacteria and other water microorganisms and considered a successful approach in different regions with illuminated periods such as Cameroon, India, Senegal, and South Africa [10]. However, conventional SODIS technology has been associated with several drawbacks, including the small and limited volume of water bottles, as efficiency of the process mainly depends on various factors including the initial level of water contamination, solar irradiance, water turbidity, time of day, and the atmospheric conditions [11]. The required time for some microbial inactivation was reviewed recently by Malato et al. [12] and reported to range from $20 \mathrm{~min}$ to $8 \mathrm{~h}$ depending on the microbe. The long period of time and unavailable direct solar power on some days are some of the known limitations of the SODIS process. However, great advances have been made in this field to enhance efficiency and overcome such issues, which can be observed from the marked accelerated increase of the number of publications each year regarding the utilization of solar disinfection of water as presented in Figure 1.

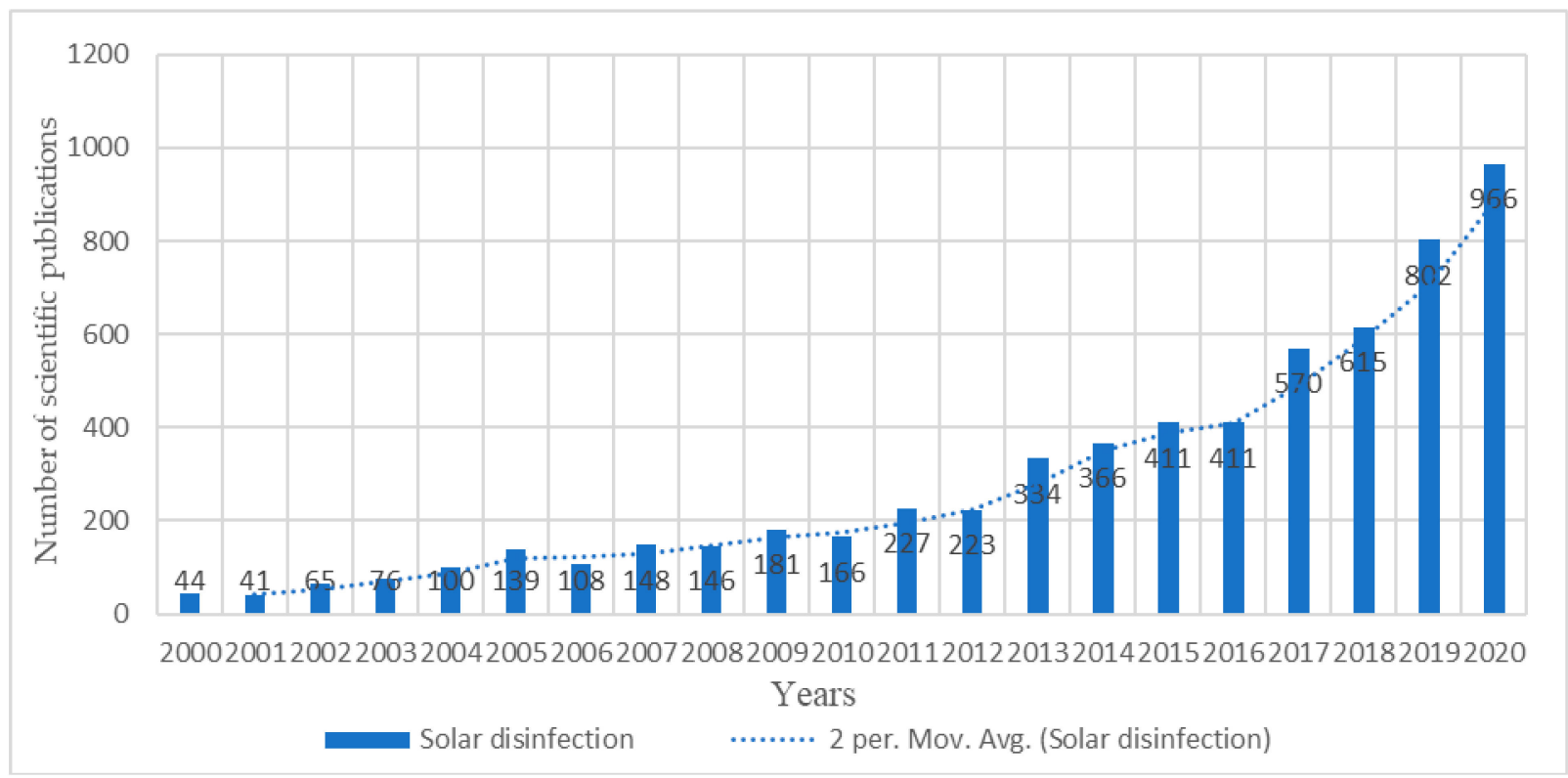

Figure 1. The number of scientific publications related to solar disinfection for the past 20 years (search done through Science Direct database on 4 September 2021 by using the keywords "Solar disinfection").

Many of these publications reviewed the mechanism of solar disinfection of microbes [13], modeling approaches to make SODIS faster [14], and photocatalytic enhancement of solar disinfection [11]. Previous reviews either discuss a particular side of the process or focus on a specific approach such as $\mathrm{TiO}_{2}$ photocatalysts [15], ozone and photocatalytic processes [16], or the application of SODIS [17]. Chaúque et al. [18] recently identified the main limitations associated with the conventional SODIS process and reviewed its potential and challenges for large-scale application as a drinking water treatment strategy. This review presents a comprehensive discussion of the SODIS process, its in- 
activation mechanism of different water microorganisms, and the factors affecting the disinfection process. Different pre-treatment techniques to enhance the disinfection efficiency of SODIS process including the use of chemical agents such as photocatalysts as well as using synthetic and natural coagulants are also discussed. Finally, the main challenges and health precautions of consuming water after its exposure to such treatment systems are covered, presenting the latest health assessment in this regard.

\section{Water Treatment Approaches}

Several methods have been developed for water treatment depending on the initial level of water quality, the type of pollution, and the availability. The applicability of these approaches has always been a great challenge in many countries, taking into consideration the cost of installation, safety, and the effectiveness. However, most of these methods are designed to have two major phases: a solid-liquid separation phase, which runs as a pretreatment step, necessarily followed by a disinfection phase (such as SODIS) [19]. The pre-treatment phase could be physical, chemical, or biological approaches, which are applied to reduce the water turbidity, resulting from dusts, oil, and/or grease. The disinfection phase is used to eliminate the microorganisms using UV or solar treatments to meet the national or international requirements [20]. Despite the cost and applicability, pretreatment approaches can be classified into three approaches including physical, chemical, or biological approaches. Physical approaches are mostly used as pretreatment steps, which include filtration, adsorption, etc. In some cases, physical approaches may be sufficient for water treatment, but in terms of water microorganisms, further steps may be required. Chemical approaches such as coagulation, precipitation, hydrolysis, etc. are not favorable in terms of drinking water due to the potential health effect for the chemical agents.

\subsection{Physical Approaches}

The physical water treatment approaches typically consist of filtration techniques that involve using any particle size-based separation such as screens and cross flow filtration membranes, in addition to adsorption, sedimentation, and distillation techniques [21]. Physical treatment approaches are typically used in numerous undeveloped and developing countries as a pretreatment method for removing larger suspended material from water. Thines et al. [22] stated two main types of adsorption for different pollutants including physisorption and chemisorption. However, physisorption occurs due to the attraction of the organic pollutant and adsorbent by van der Waals force, which is a weak force $(0.4-4.0 \mathrm{~kJ} / \mathrm{mol})$ resulting from electrical interactions between two or more atoms or molecules that are very close to each other, compared with the strong chemical bond such as hydrogen bonds, ionic interactions, and hydrophobic interactions $(15,20$, and $<40 \mathrm{~kJ} / \mathrm{mol}$, respectively) that may result between the surface of the adsorbent and the organic pollutant in chemisorption. Refer to Table 1 for a summary of conventional physical approaches for water treatment.

Table 1. Illustration of different physical approaches for water treatment.

\begin{tabular}{ccc}
\hline Physical Approach & The Principle & Ref. \\
\hline Adsorption & $\begin{array}{c}\text { The adsorbent attracts organic and inorganic pollutants, leading to their } \\
\text { accumulation onto its surface and eventually precipitate }\end{array}$ & [23] \\
\hline Filtration & $\begin{array}{c}\text { Passing of water through a permeable membrane containing small pores able } \\
\text { to trap the desired pollutant. }\end{array}$ & [24] \\
\hline Sedimentation & Removing the suspended solids from water by means of gravity or separation. & [25] \\
\hline
\end{tabular}

\subsection{Chemical Approaches}

The chemical water treatment approach involves using chemicals in an array of procedures to expedite purification or separation of the water pollutant. Chemical approaches consist of various reactions that eventually lead to neutralization and hydrolyzing the 
water pollutants into harmless chemicals [26]. Salimi et al. [27] stated that coagulation and advanced oxidation processes are the main chemical methods in water treatment processes, which also include ozonation and Fenton treatment. These approaches are usually followed by photocatalysis and/or membrane techniques. The chlorination technique has been also used prior to powdered activated carbon filtration as a two-step water treatment approach [28]. Advanced oxidation is a technique that consists of using oxidizing agents for the oxidation of the pollutant [29]. Various advantages have been reported to this technique such as rapid reaction rates compared to similar techniques, not requiring a large area for processing the water, and less retention time [30].

\section{Solar Disinfection and Water Treatment}

Solar water disinfection, or simply SODIS, is a water disinfection process widely known in many African and Asian countries as a simple and low-cost treatment approach to eliminate the pathogenic microorganisms from drinking water [31]. The SODIS process is not a recent technology, numerous studies give descriptions of this approach in ancient India over 2000 years ago, with the water being placed in open trays outside in the sun [32]. However, the exact role and the mechanism of microbial disinfection was discovered during the 20th century when Aftim Acra et al. conducted and published a similar work explaining how sunlight disinfects water microorganisms [33,34]. Since then, a significant number of studies have been conducted revealing the great potential of SODIS in inactivating pathogenic microorganisms in water $[35,36]$.

\subsection{Mechanisms of Solar Disinfection}

Recent investigation revealed that the microbial disinfection in the SODIS process is caused by the effect of two main factors, namely increasing the temperature resulting from light exposure and UV (A and B) of the solar rays [37]. Most UVC is absorbed while the rays pass through the atmosphere and the germicidal effect of UVB is significantly stronger than that of UVA (100 and 1000 times). UVB was found to pass through the atmosphere and reach natural water bodies, leading to a significant disinfection effect due to the induction of mutations and possibly apoptosis as well as imminent cell death [38]. Different studies have confirmed the effect of high temperature resulting from solar exposure on different water microorganisms, especially its synergistic effect with UV radiation that comes with solar radiation, which accelerates the disinfection process [39]. The short wavelengths of UVB (280-320 nm) are highly absorbable by the nucleic acid of living organisms within the water, causing severe damage in the genetic material and eventually causing their disinfection [40]. Numerous investigations have recently been conducted to confirm the ability and the mechanisms of sunlight to inactivate different standard microorganisms including bacteria, viruses, and fungi, in addition to protozoa and some helminths [3,41-43].

\subsubsection{Bacterial Disinfection}

Bacterial cells contain regulators of reactive oxygen species (ROS) to naturalize any byproduct resulting from cellular oxidative metabolism or imbalances that may be generated within the bacterial cells in addition to withstanding the production of reactive oxygen species by enzyme auto-oxidation [44]. Escherichia coli is known to be the most frequently studied species, as pathogenic waterborne bacteria and the main pathogen indicators in drinking water [45]. Solar light was found to affect the endogenous photosensitizers in bacterial cells in addition to ROS production upon exposure to solar light. Reactive oxygen species have been reported to cause cellular damage by initiating a variety of cellular reactions such as intracellular oxidation [46]. Berney et al. [47] investigated the inactivation of this species using the SODIS system and revealed that bacterial disinfection was mainly caused by the massive disrupting of cellular function. Upon solar exposure, efflux pump activity and the synthesis of ATP energy compounds cease shortly in the initial minutes and accelerated by time, leading to a reduction in glucose uptake and gradual loss of membrane potential. Finally, the bacterial cell membrane becomes 
highly permeable, and thus the inactivation occurs [48]. Catalase enzyme is the most known defense line for most bacteria in addition to Ahp Alkyl hydroperoxide reductase, glutathione reductase (GR), hydroperoxidases (HPI, HPII), and superoxide dismutases (FeSOD, MnSOD) [49]. Decomposition of hydrogen peroxide was found to be caused by a catalase enzyme, while scavenging the normally production of hydrogen peroxide in E. coli is the function of Ahp Alkyl hydroperoxide reductase enzyme [50]. Many studies stated that $\mathrm{H}_{2} \mathrm{O}_{2}$ itself is not harmful to bacterial DNA; however, some studies reported that oxidation of adenine can be caused by $\mathrm{H}_{2} \mathrm{O}_{2}$ production. $\mathrm{H}_{2} \mathrm{O}_{2}$ may also engulf and eliminate the adverse effect of hydroxyl radical and thus, its accumulation could be a sign of cell survival [51]. Gomes et al. [52] stated that when the bacterial cells are exposed to solar light, several reactions occur as consecutive events following complex mechanisms, which may be inhibited in some bacteria by the synergistic effect of ROS and the action of light. However, prolonged exposure to UVB was found to have direct effect on catalase functions in E. coli cells, and therefore enhance $\mathrm{H}_{2} \mathrm{O}_{2}$ accumulation [53]. UVA irradiation is responsible for excess production of singlet oxygen, which is an essential factor in bacterial cytotoxicity and gene expression through excitation of porfyrins and other chromophoric substances [54]. Catalase (CAT) and superoxide dismutase (SOD) are another two key enzymes in bacterial disinfection by solar light action. The reduction in these enzymes was found to be even worse than the over accumulation of ROS inside the bacterial cell. Some previous studies proposed that the excess $\mathrm{H}_{2} \mathrm{O}_{2}$ accumulation inside the cell followed by the subsequent reactions could lead to genetic mutations and possible cellular apoptosis, which is also accelerated by solar light [55].

\subsubsection{Viral Disinfection}

Viruses are obligate intracellular parasites, do not have a cell membrane, and are present in many environments including water. The endogenic inactivation process of these microorganisms is less important compared to the bacteria [48]. It has been reported that virus inactivation by the SODIS process occurs by damaging the viral genome by reactive oxygen species resulting from dissolved photosensitizers in the water. However, blocking of the UVB rays was found to prevent direct inactivation of viruses in PET bottles, and the inactivation was said to be dependent on initial water quality [56]. In a recent investigation, Sagripanti et al. [57] estimated the potential of solar radiation in COVID-19 inactivation as double-stranded viruses compared with previous reports of single-stranded RNA viruses. The authors found that double-stranded viruses should be inactivated relatively faster than single-stranded upon exposure to solar light. In contrast to bacteria, viruses are known for their simple structure that consists of protein capsid surrounding their genetic material. Some viruses contain endogenous chromophores, able to absorb the visible range of UVA light. Kohn et al. [58] stated that indirect photoinactivation of viruses in aquas media can entirely depends on many factors (even in low concentrations), including exogenous presence, organic matter, nitrate, nitrite, and the constituents of iron-containing solution, which can significantly aid in sunlight absorption and thus produce reactive oxygen species such as $\mathrm{H}_{2} \mathrm{O}_{2}, \mathrm{O}_{2}{ }^{-}, \mathrm{O}_{2}$, and $\mathrm{OH}^{-}$. Studies evaluating the effect of SODIS process against different viruses that are commonly present in water are scarce. Many viruses including bacteriophage, bovine rotavirus, and somatic phage were completely inactivated at three logarithm unit reduction in solar exposure in less than $3 \mathrm{~h}[59,60]$. Safapour and Metcalf [61] reported that Enterobacteria phage T2 was viable (able to infect the bacterial cells) at $62{ }^{\circ} \mathrm{C}$, partially inactivated at $65^{\circ} \mathrm{C}$, and completely inactivated at $70^{\circ} \mathrm{C}$ in $1.5 \mathrm{~h}$. In a different study, viable FRNA coliphages were detected in SODIS reactors fitted with reflectors (increasing the water temperature by an additional $8-10^{\circ} \mathrm{C}$ to $64-75^{\circ} \mathrm{C}$ ) even though $E$. coli was easily disinfected under identical conditions [62]. These viruses have the ability to resist the SODIS process by developing several protection mechanisms. In a similar investigation, Harding and Schwab [63] were also unable to reduce the viable murine noro-virus populations by using solar based 
UVA light, revealing the potential of these microorganisms to develop resistance to such conventional treatment systems.

\subsubsection{Disinfection of Other Water Microbes}

Other water microorganisms including fungi, protozoa, and some helminths can be found in water sources and may realistically be classed as serious waterborne human pathogens. Most fungal disinfection studies using the SODIS process have concentrated on plant fungi [64]. However, Lonnen et al. [65] demonstrated that Candida albicans is readily inactivated after $6 \mathrm{~h}$ of solar exposure. Many protozoan pathogens commonly present in water such as Cryptosporidium spp., Giardia lamblia, and amoebae were reported to be more resistant to the SODIS process than bacteria and viruses [66]. Many waterborne protists possess, during several phases of their life, a thick-walled chitinous-cysts or oocysts; these strong structures protect them from undesirable conditions including the conventional SODIS process as well as other forms of disinfection such as chlorination and even boiling [67]. García-Gil et al. [48] reported that disinfection of protozoa and fungi is done through endogenous photo-inactivation mechanisms, which is similar to viral disinfection (through the action of UVB). However, it has been reported that impure water can enhance exogenous indirect damage, and thus the inactivation of bacteria as well as viruses, but not for other microorganisms such as protozoa. Exogenous indirect damage for protozoa and some fungi is generally negligible as they are characterized by a thick resistant oocyst-wall [68]. Inactivation of protozoa is a multifaceted mechanism depending on many factors such as the microbial species and its physiological state in addition to time of exposure and radiation wavelength. Natural solar light was found to be enough to deactivate many protozoa such as Cryptosporidium parvum protozoon by direct genome damage produced by the UVB radiation [69].

\subsection{SODIS Effectiveness and Impact}

SODIS is a simple process that depends on few factors associated with the initial quality of water to be treated, the container, and the weather in terms of solar irradiation, and weather in terms of temperature. The effectiveness of SODIS has been confirmed for various types of water microorganisms, including bacteria, fungi, viruses, and protozoa [18]. In order to achieve safe inactivation of water microorganisms, a significant number of studies reported the importance of gathering both the optical and thermal effect resulting from solar radiation to accelerate the inactivation process [39,70]. The synergistic effect of thermal and optical effect rays mainly depends on the initial water quality and the type of container in addition to the seasonal and environmental factors.

\subsubsection{Initial Water Quality and Type of Container}

The SODIS process involves placing the water (untreated or partially treated) into a specific container in most cases made from plastic or glass and then exposing it to direct sunlight for a certain period of time before drinking [1]. Glass containers considered more transparent and can be used to provide better sunlight penetration, but they have been linked with many drawbacks including blocking UV radiation, high expenses, fragility, and weight, making use of polyethylene terephthalate (PET) or polyethylene (PE) [71,72]. Turbidity of water was also found to affect the permeability of solar light; Chauque et al. [73] found that in water with less than $1 \mathrm{NTU}$, the water temperature reached $55^{\circ} \mathrm{C}$, which was found to be enough for the inactivation of Acanthamoeba castellanii cysts, Salmonella typhimurium, E. coli, Enterococcus faecalis, and P. aeruginosa in only $0.5 \mathrm{~min}$. However, with turbid water (50 NTU). the same inactivation results were only achieved when the temperature reached $60^{\circ} \mathrm{C}$ [73]. Amirsoleimani and Brion [74] stated that the inactivation of $E$. coli markedly decreased (from 5 to $1 \log$ ) with the increase of water turbidity from 0 to 200 NTU. The authors followed the same protocol and found that more than 4-log inactivation of two Gram-positive bacteria (Staphylococcus epidermidis and Staphylococcus aureus) was achieved. Pretreatment of water to obtain minimal turbidity is important to 
achieve the synergy of the thermal and optical effects of solar irradiation and thus better water disinfection. Microbial disinfection could be achieved by any or both of these effects, depending on exposure time, the type of microorganism, and the intensity. Even enough heat without solar radiation or in high turbidity may kill the bacteria, the presence of solar light and less turbidity will significantly enhance and speed up the disinfection process even with the thermal effect of solar power.

\subsubsection{Environmental Factors}

Being an environment-dependent process, SODIS is highly dependent on the weather and solar intensity, which is the major set-back in many countries. Prolonged periods are required in cloudy weather or during cold season to achieve satisfactory water disinfection. Luzi et al. [75] stated that on a clear sunny day, $6 \mathrm{~h}$ of exposure is enough compared with cloudy conditions. The effectiveness of SODIS was found to be the best in locations with significant amounts of strong sunlight during midday, mostly located around the equator [76]. Various studies have been conducted to overcome the weather issue in term of partially sunny or during cold season and enhance SODIS; Sommer et al. [77] suggested using darker containers or painting the underside of them with black to enhance the thermal disinfection. However, this could increase the water temperature, but it will prevent the penetration of solar irradiation through the water and minimize the action of endogenous photo-inactivation (through the action of UVB) [62]. Other studies reported using concentrators or reflectors to increase solar ray intensity and enhance water exposure [78,79]; using such method could significantly reduce the required exposure time and those utilize the partial sunny weather. In monsoon and winter seasons, it has been reported that log reduction value $>4$ can be achieved for an exposure time to sunlight of around $17 \mathrm{~h}$ due to the significant low temperature in some countries, which may require the use of reflective reactors [39]. However, in hot seasons, only 6 to $8 \mathrm{~h}$ were found to be enough to achieve log reduction value of over 5 even by using the conventional PET reactors $[17,39]$.

\subsubsection{Resistance of Water Microorganisms}

Despite the high sensitivity of most waterborne microorganisms to solar disinfection (thermal and optical effect) and them being easily inactivated by different intensities and different time, some studies have pointed out the ability of certain pathogens to develop resistance and adaptation to such conditions [80]. It has been reported that these pathogens, which include many forms of protozoa (such as Cryptosporidium parvum and Acanthamoeba spp.) and bacterial spores (such as Bacillus subtilis spores) are also more likely to resist conventional disinfection processes such as chlorination and ozonation [81,82]. Although SODIS has proven its ability to inactivate or considerably reduce the viability of most important and common waterborne disease such as E. coli, total and fecal coliforms as reported in many studies, the more recalcitrant the pathogen is, the higher doses of solar radiation and longer the exposure time will be required for its inactivation. Fiorentino et al. [83] stated that chlorination with only $1 \mathrm{mg} / \mathrm{L}$ was found to be more effective against the vegetative and non-spore-forming bacteria, particularly $E$. coli, than the use of $\mathrm{H}_{2} \mathrm{O}_{2}(50 \mathrm{mg} / \mathrm{L})+\mathrm{SODIS}$. However, the same authors found that chlorination was less effective in controlling the regrowth of the same bacteria; the percentage of $E$. coli in SODIS treated samples significantly decreased with the increase in incubation time, which was the opposite in the chlorinated samples [83]. SODIS was effective against chlorine-resistant microorganisms. Table 2 presents a summary of the literature regarding drinking water pathogens and their profile of resistance to SODIS. 
Table 2. The effect of SODIS against chlorine-resistant microorganisms.

\begin{tabular}{|c|c|c|c|c|c|c|}
\hline Microbial Species & $\begin{array}{l}\text { Treatment } \\
\text { Condition }\end{array}$ & Optical Effect $\left(\mathrm{W} / \mathrm{m}^{2}\right)$ & Thermal Effect & Time & Inactivation & Ref \\
\hline $\begin{array}{c}\text { Acanthamoeba castellanii } \\
\text { (cysts) }\end{array}$ & $\begin{array}{l}\text { Simulated sunlight } \\
\text { conditions }\end{array}$ & 550 (UV B) & $\leq 45$ & $6 \mathrm{~h}$ & 2.2-log & [66] \\
\hline $\begin{array}{c}\text { Cryptosporidium parvum } \\
\text { (oocysts) }\end{array}$ & $\begin{array}{l}\text { Simulated sunlight } \\
\text { conditions }+\mathrm{TiO}_{2}\end{array}$ & $\begin{array}{c}870 \text { and } 200 \text { (UV B and A } \\
\text { respectively) }\end{array}$ & $40^{\circ} \mathrm{C}$ & $6 \mathrm{~h}$ & 5.9- $\log$ & [84] \\
\hline $\begin{array}{c}\text { Acanthamoeba castellanii } \\
\text { (cysts) }\end{array}$ & $\mathrm{NaCl}$ and $\mathrm{NaOCl}$ & 243 (UV C) & $55^{\circ} \mathrm{C}$ & $2 \mathrm{~h}$ & 6-log & [85] \\
\hline $\begin{array}{c}\text { Cryptosporidium parvum } \\
\text { (oocysts) }\end{array}$ & $\begin{array}{l}\text { Simulated sunlight } \\
\text { conditions }+\mathrm{Cl}_{2}\end{array}$ & - & $25^{\circ} \mathrm{C}$ & $1 \mathrm{~h}$ & $>2-\log$ & [86] \\
\hline Bacillus subtilis spores & $\begin{array}{l}\text { Simulated sunlight } \\
+\mathrm{TiO}_{2}\end{array}$ & $\begin{array}{c}870 \text { and } 200 \text { (UV B and } \mathrm{A} \\
\text { respectively) }\end{array}$ & $40^{\circ} \mathrm{C}$ & $8 \mathrm{~h}$ & $1.1-\log$ & [65] \\
\hline
\end{tabular}

\subsection{Enhancement Approaches for Solar Disinfection of Water}

The past few years witnessed a significant number of studies aiming to enhance the efficiency of the SODIS process and overcome its limitations by using a photocatalyst, pretreatment of water, or using continuous flow-based systems.

\subsubsection{Enhancement of SODIS Using Photocatalyst}

Advanced oxidation processes have recently been used as a promising option for drinking water treatment as well as simultaneous mineralization of organic matter [87]. A photo-assisted Fenton process has been successfully coupled with SODIS for the enhancement of bacterial inactivation. This process combines three main factors including $\mathrm{Fe}^{2+}$, $\mathrm{H}_{2} \mathrm{O}_{2}$, and light [88]. Non-selective ROSs resulting from the consumption of $\mathrm{H}_{2} \mathrm{O}_{2}$ are the main effective factors in this deactivation process, which was found to inactivate most of pathogenic bacteria present in water. Shekoohiyan et al. [89] fabricated an iron oxide-based film to enhance the process of solar disinfection. The film was placed inside the plastic bottles (PET bottles) for better bactericidal capacity. The authors were able to enhance SODIS and reduce the exposure time by $60 \%$ in addition to significantly eliminating microbial regrowth. Titanium dioxide nanoparticles have been used as a photocatalytic water treatment to degrade organic pollutants and eliminate the pathogenic microorganisms [90]. Owing to its safety and non-toxicity, availability, and low cost, as well as its high photocatalytic activity, titanium dioxide $\left(\mathrm{TiO}_{2}\right)$ has gained the attention of many scientists although there are some remaining concerns about the separation of the nanoparticles from treated water. Metal oxide nanoparticles have been reported to display photocatalytic activity, resulting in the elimination of microbial growth. Zinc oxide nanoparticles possess many desirable properties such as its unique surface reactivity that is attached to many active sites, making them emergent and efficient nanophotocatalysts as compared to titanium dioxide [91]. However, some studies have concluded that nano-sized zinc oxide exhibited toxicity even at lower doses [92-94]. Pasupuleti et al. [95] reported that the incidences of microscopic lesions in liver, pancreas, heart, and stomach treated rates were higher in lower doses of nano-sized zinc oxide compared to higher doses, while for micro-sized zinc oxide, the incidences of the above lesions were higher in rats treated with a high dose. The inability to control the dose of zinc oxide in poor villages is still a great challenge that has restricted its usage. Reddy et al. [96] investigated silver-loaded $\mathrm{TiO}_{2}$ nanoparticles supported on hydroxyapatite to enhance solar disinfection using $E$. coli bacteria in aqueous media, which showed $100 \%$ killing of $E$. coli within only $2 \mathrm{~min}$. The separation of titanium dioxide is still a major challenge, as this photocatalyst is mostly used in slurry systems, thus the separation will increase the cost of the treatment process. However, immobilization of the photocatalyst on specific carriers such as films can overcome the extra costs of doing the separation step, especially for the household and treatment of small volumes of water. 
It can also be a possible future water treatment approach in industrialized countries using renewable solar energy [97]. Photocatalytic materials have the advantage of the ability to be deposited on flexible substrates as coating agents, due to their high flexibility nature. Numerous studies reported the fabrication of photocatalytic coatings on a wide range of substrates for water treatment and other applications [98,99]. It is well known that upon using $\mathrm{TiO}_{2}$, both hydroxyl and superoxide radicals are generated, which act as a catalyst under direct sunlight (UVA). ROSs including $\mathrm{HO}$ and $\mathrm{O}_{2}{ }^{-}$generated from $\mathrm{TiO}_{2}$, which are able to oxidize and convert most of the organic molecules to simpler forms or induce mineralization (complete oxidization to $\mathrm{CO}_{2}$ and $\mathrm{H}_{2} \mathrm{O}$ ) [100]. $\mathrm{H}_{2} \mathrm{O}_{2}$ and singlet oxygen are other oxidative species that may be generated, which also react together with hydroxyl radicals and superoxide, resulting in bacterial deactivation due to the excessive damage of their cell membrane and genetic material [101].

Carbon nanoparticles have recently received great attention among scientists, due to their hydrophobic nature and high surface area of nanoparticles [102]. In addition to their adsorption role, carbonaceous nanomaterials have photothermal or photocatalytic properties, making them highly desired in water treatment applications. The antibacterial activity of these materials is based on the photothermal heat produced by the nanoparticles when exposed to sunlight (photon energy) [103]. Many studies revealed that the physical interaction between carbon nanoparticles and the microorganisms can be crucial for solar disinfection; exposing polyethylene terephthalate bottles of contaminated water for a certain period of time can lead to $100 \%$ killing of all the microorganisms [104]. Malato et al. [12] reported that the use of photocatalysts was found to significantly shorten the required time for total disinfection. Carbon nanoparticles induce physical damage to bacterial cells as a result of their interaction, which can be desirable and helpful for the SODIS process. Upon the exposure of contaminated water in PET bottles to direct sunlight for a certain period of time, carbon nanomaterials were found to enhance the description of bacterial cell membrane. Owing to the generation of photo-thermal heat, when these nanoparticles are exposed to sunlight, there is a similar mechanism to cancerous cells destruction [105]. In a recent investigation, Maddigpu et al. [106] prepared composites from chitosan and carbon nanoparticles by the solution-casting approach and studied its inactivation efficiency towards $E$. coli bacteria under sunlight. The authors reported that the composite significantly enhanced SODIS as compared to the control with higher bactericidal efficiency. In a different study, Larlee [107] investigated using a low-tech photocatalyst for solar water disinfection and color removal. The authors used different bare clays as photocatalysts for the SODIS process, and revealed the ability to inactivate E. coli within only $1 \mathrm{~h}$ of sunlight exposure, suggesting bare clays as cheap material for potential photocatalysts for SODIS. Refer to Table 3 for a summary of literature regarding the enhancement of SODIS using different photocatalysts.

Table 3. Summary of the literature regarding the enhancement of SODIS using different photocatalyst.

\begin{tabular}{ccccc}
\hline Photocatalyst & $\begin{array}{c}\text { Microorganisms } \\
\text { Tested }\end{array}$ & $\begin{array}{c}\text { Enhancing the } \\
\text { Inactivation Rate }\end{array}$ & Time & Condition \\
\hline $\begin{array}{c}\text { Composite } \mathrm{TiO}_{2} / \mathrm{SiO}_{2} / \mathrm{Au} \\
\text { films }\end{array}$ & $\begin{array}{c}\text { E. coli, total } \\
\text { coliforms, and } \\
\text { Enterococci }\end{array}$ & $\begin{array}{c}1.5,1.3 \text {, and } 1.6 \text { fold } \\
\text { survival decrease }\end{array}$ & 24 to $72 \mathrm{~h}$ & $\begin{array}{c}\text { Under natural } \\
\text { solar radiation }\end{array}$ \\
\hline $\begin{array}{c}\text { photo-Fenton system } \\
\left(\mathrm{Fe}^{3+} / \mathrm{H}_{2} \mathrm{O}_{2} / \mathrm{hv}\right)\end{array}$ & E. coli & Increased by 355\% & 240 min & $\begin{array}{c}\text { Under natural } \\
\text { solar radiation and } \\
\text { natural pH }\end{array}$ \\
\hline [109]
\end{tabular}


Table 3. Cont.

\begin{tabular}{|c|c|c|c|c|c|}
\hline Photocatalyst & $\begin{array}{c}\text { Microorganisms } \\
\text { Tested }\end{array}$ & $\begin{array}{l}\text { Enhancing the } \\
\text { Inactivation Rate }\end{array}$ & Time & Condition & Ref. \\
\hline ZnO Nanorods & E. coli & $\begin{array}{l}\text { 2.5-fold survival } \\
\text { decrease after }\end{array}$ & $180 \mathrm{~min}$ & $\begin{array}{l}\text { Under simulated } \\
\text { sunlight of low } \\
\text { intensity }\end{array}$ & [110] \\
\hline $\mathrm{TiO}_{2}$ & $\begin{array}{l}\text { Cryptosporidium } \\
\text { parvum }\end{array}$ & $\begin{array}{c}\text { Enhanced SODIS } \\
\text { elimination from } 81.3 \% \\
\text { to } 98.3 \%\end{array}$ & $8 \mathrm{~h}$ & $\begin{array}{l}\text { Cloudy solar } \\
\text { irradiance }\end{array}$ & [111] \\
\hline $\mathrm{TiO}_{2} / \mathrm{SiO}_{2}$ thin films & $\begin{array}{l}\text { Vibrio spp., } \\
\text { Enterococci, and } \\
\text { E. coli }\end{array}$ & $\begin{array}{l}\text { Enhanced SODIS } \\
\text { elimination by } 27 \%\end{array}$ & $80 \mathrm{~min}$ & $\begin{array}{l}\text { Under natural } \\
\text { solar light }\end{array}$ & [108] \\
\hline $\begin{array}{c}\mathrm{Fe}_{2} \mathrm{O}_{3}-\mathrm{TiO}_{2} \text {-based } \\
\text { nanoparticles }\end{array}$ & Vibrio fischeri & $\begin{array}{c}99.4 \% \text { inactivation } \\
\text { efficiency }\end{array}$ & $240 \mathrm{~min}$ & $\begin{array}{l}\text { Visible light } \\
\text { irradiation at } \\
\text { different } \\
\text { temperatures }\end{array}$ & [112] \\
\hline Nano-structured $\mathrm{ZnO}$ & E. coli & $\begin{array}{c}15 \% \text { higher } \\
\text { disinfection efficiency }\end{array}$ & $15 \mathrm{~min}$ & $\begin{array}{l}\text { Under actual } \\
\text { sunlight }\end{array}$ & [113] \\
\hline $\begin{array}{c}\mathrm{TiO}_{2} \text { nanoparticles and } \\
\mathrm{ZnO} / \mathrm{TiO}_{2}\end{array}$ & $\begin{array}{l}\text { Enterobacter, } \\
\text { Klebsiella and } \\
\text { pseudomonas }\end{array}$ & $\begin{array}{l}\text { Reduction of bacteria } \\
\text { from } 3.6 \times 10^{8} \text { to } \\
1.63 \times 10^{4} \mathrm{CFU}\end{array}$ & - & $\begin{array}{l}\text { UV lamp and solar } \\
\text { radiation }\end{array}$ & [114] \\
\hline $\mathrm{TiO}_{2}$ nanoparticles & E. coli & $\begin{array}{c}\text { Total inactivation } \\
\text { (6.5-log) compared } \\
\text { with 4-log without } \\
\mathrm{TiO}_{2}\end{array}$ & $240 \mathrm{~min}$ & $\begin{array}{l}\text { Under solar } \\
\text { conditions }\end{array}$ & {$[72]$} \\
\hline Boron-doped $\mathrm{ZnO}$ & $\begin{array}{c}\text { E. coli and } \\
\text { Enterococcus sp. }\end{array}$ & $\begin{array}{c}\text { Total inactivation } \\
\text { (3-log) compared with } \\
\text { 1-log of } \mathrm{ZnO}\end{array}$ & $180 \mathrm{~min}$ & $\begin{array}{l}\text { Under solar } \\
\text { simulated } \\
\text { irradiation. }\end{array}$ & [115] \\
\hline $\mathrm{Fe}^{3+}$ and $\mathrm{H}_{2} \mathrm{O}_{2}$ & $\begin{array}{c}\text { E. coli and Klebsiella } \\
\text { pneumoniae }\end{array}$ & $\begin{array}{l}\text { Complete inactivation } \\
\text { of } E \text {. coli, but } K \text {. } \\
\text { pneumoniae decreased } \\
\text { only } 1-\log \text {. }\end{array}$ & $350 \mathrm{~min}$ & $\begin{array}{l}\text { Under simulated } \\
\text { solar light }\end{array}$ & [116] \\
\hline
\end{tabular}

\subsubsection{Coagulant Pre-Treatment to Solar Disinfection}

Most of water bodies possess a certain level of turbidity, resulting from dissolved and suspended organic materials as well as microorganisms, which are able to block or limit the penetration of sunlight through the untreated water during solar disinfection [93]. Thus, many scientists suggested pre-treatment of turbid water to less than 30 NTU before using SODIS [117]. Numerous methods have been used to reduce turbidity including a variety of filtration techniques, gravity settling, centrifuge force, and the use of natural and synthetic coagulants/adsorbents [118]. The use of natural coagulants followed by a filtration process is highly preferable compared to synthetic coagulation agents due to cytotoxicity concerns. In a recent investigation, Keogh et al. [119] used Moringa oleifera as a flocculating agent to reduce turbidity as a pre-treatment for SODIS. The authors reported that this flocculating agent was able to reduce the turbidity of water samples, leaving a bio-active sludge layer in the bottoms of the bottles. After $24 \mathrm{~h}$ of Moringa oleifera treatment, the authors reported impressive reduction in water microorganisms compared with untreated turbid controls. In a different study, an aqua lens coupled with the natural coagulant (Moringa oleifera) was found to be effective as an eco-friendly and safe treatment approach for households, which showed great potential in enhancing the efficiency of solar disinfection [120]. Natural coagulants that release lower sludge quantity are preferable as the post-separation costs will be reduced and the natural alkalinity of water is retained during the process of the water treatment [121]. The seed powder of Strychnos potatorum is another effective natural 
coagulant, which was tested by Arafat and Mohamed [122]. The authors reported 90-99\% removal of water bacteria after using this natural coagulant in addition to its coagulation role. Carica papaya seeds are another natural coagulant obtained from tropical trees and characterized by cystine protease proteins (water-soluble and positively charged proteins), which are also utilized as a putative natural coagulant [123]. In a study done by Unnisa et al. [124], Carica papaya seeds were used as a pre-treatment for SODIS to reduce water turbidity and inactivate coliform bacteria. The authors reported $100 \%$ removal efficiency for turbidity even at the minimum concentrations of natural coagulant in only $30 \mathrm{~min}$. The time for SODIS was reduced to $2 \mathrm{~h}$, which was enough to achieve $100 \%$ removal of coliform bacteria from the water. Limited studies have been done on coupling natural coagulant with the SODIS process. Table 4 presents a summary of studies of using natural coagulants to reduce the water turbidity and coupling them with the SODIS process.

Table 4. Summary of the literature on using coagulant pretreatment for SODIS process.

\begin{tabular}{|c|c|c|c|c|c|c|c|}
\hline Coagulant & $\begin{array}{c}\text { Initial } \\
\text { Turbidity }\end{array}$ & $\begin{array}{l}\text { Enhanced } \\
\text { Turbidity }\end{array}$ & $\begin{array}{c}\text { Microorganisms } \\
\text { Tested }\end{array}$ & $\begin{array}{c}\text { Inactivation } \\
\text { Rate }\end{array}$ & Time & Condition & Ref \\
\hline $\begin{array}{l}\text { Powdered Moringa } \\
\text { oleifera seeds }\end{array}$ & $200 \mathrm{NTU}$ & $28.5 \mathrm{NTU}$ & E. coli & 6-log & $6 \mathrm{~h}$ & $\begin{array}{c}\text { Direct } \\
\text { sunlight }\end{array}$ & [119] \\
\hline Opuntia cochenillifera & $111 \mathrm{NTU}$ & $7.83 \mathrm{NTU}$ & E. coli & 2.86-log & $12 \mathrm{~h}$ & $\begin{array}{c}\text { Under } \\
\text { natural } \\
\text { sunlight }\end{array}$ & [125] \\
\hline $\begin{array}{l}\text { Maerua subcordata or } \\
\text { Moringa stenopetala }\end{array}$ & $150 \mathrm{NTU}$ & $10 \mathrm{NTU}$ & Fecal coliforms & $\begin{array}{l}\text { Complete } \\
\text { removal }\end{array}$ & $4 \mathrm{~h}$ & $\begin{array}{c}\text { Under } \\
\text { natural } \\
\text { sunlight }\end{array}$ & [126] \\
\hline Carica papaya seeds & $60 \mathrm{NTU}$ & $0 \mathrm{NTU}$ & $\begin{array}{l}\text { E. coli and } \\
\text { coliforms }\end{array}$ & $\begin{array}{l}\text { Complete } \\
\text { removal }\end{array}$ & $2 \mathrm{~h}$ & $\begin{array}{c}\text { Under } \\
\text { natural } \\
\text { sunlight }\end{array}$ & [124] \\
\hline Moringa oleifera & $150 \mathrm{NTU}$ & $3 \mathrm{NTU}$ & $\begin{array}{l}\text { Total and fecal } \\
\text { coliforms }\end{array}$ & $99 \%$ removal & $6 \mathrm{~h}$ & $\begin{array}{c}\text { Under } \\
\text { natural } \\
\text { sunlight }\end{array}$ & [127] \\
\hline Artemisia annua & - & - & $\begin{array}{l}\text { E. coli, B. subtilis, } \\
\text { and E. faecalis }\end{array}$ & 6-log & $6 \mathrm{~h}$ & $\begin{array}{l}\text { Under } \\
\text { natural } \\
\text { sunlight }\end{array}$ & [128] \\
\hline
\end{tabular}

\subsection{Continuous Flow SODIS System}

In the photocatalytic disinfection process using normal sunlight, it was found that using photocatalysts (semiconductors) with suitable optical band-gap for the generation of reactive oxygen species in the presence of solar-light can significantly enhance the inactivation of microorganisms [35,129]. Several solar light/visible light metallic and even non-metallic photocatalysts have been investigated and proven to have a significant photocatalytic potential at laboratory scale [130,131]. Zhang et al. [132] stated that the operational costs can be reduced by immobilizing the visible light photocatalysts to avoid the requirement of photocatalyst separation phase. Mbonimpa et al. [38] developed a continuous-flow reactor based on SODIS by ultraviolet $\mathrm{B}$ radiation. For the reactor, the authors used a quartz tube with an internal diameter of $2.25 \mathrm{~cm}$ and placed the tube in the focus of a solar collector of compound parabolic with $125 \mathrm{~cm}$ long and $42 \mathrm{~cm}$ opening. Significant reduction in E. coli count was achieved, which was believed to be due to the exposure of the raw water for less than an hour and the marked increase in water temperature. Chauque et al. [73] developed a novel continuous-flow system that combines both the effect of optical and thermal solar radiation with the recirculation of water. The authors designed the system to have both disinfection mechanisms of SODIS using parabolic trough concentrator to increase water temperature with a thermoabsorbent tube in the focus of the concentrator. Furthermore, the UV irradiator of solar 
power was a Fresnel collector, which joined the parabolic trough with the concentrator, and then the authors placed tubular quartz reactors (where the water circulates) in the focus of the concentrators. The authors reported that water temperature reached $70{ }^{\circ} \mathrm{C}$, which then allowed it to flow through the irradiator for several minutes and thus full inactivation of all cysts as well as water bacteria was achieved [73]. In another recent study, Roshith et al. [133] reported a novel technique for a continuous flow water disinfection process by using red phosphorus-based photocatalyst. The authors immobilized crystalline red phosphorus in the inner walls of quartz capillary tube using a solid-state approach. The process of continuous water treatment was achieved under direct sunlight using the set-up as an optofluidic reactor and continuous flow photocatalytic (Figure 2). The reactor with the immobilized photocatalyst was able to reduce $99.99 \%$ of the E. coli in only 14 min when it was tested under direct sunlight. Furthermore, the authors reported that no visible colonies were found from the water samples of 28 min exposure time, which confirms the high efficiency of this process and its promising potential for commercial scale-up.

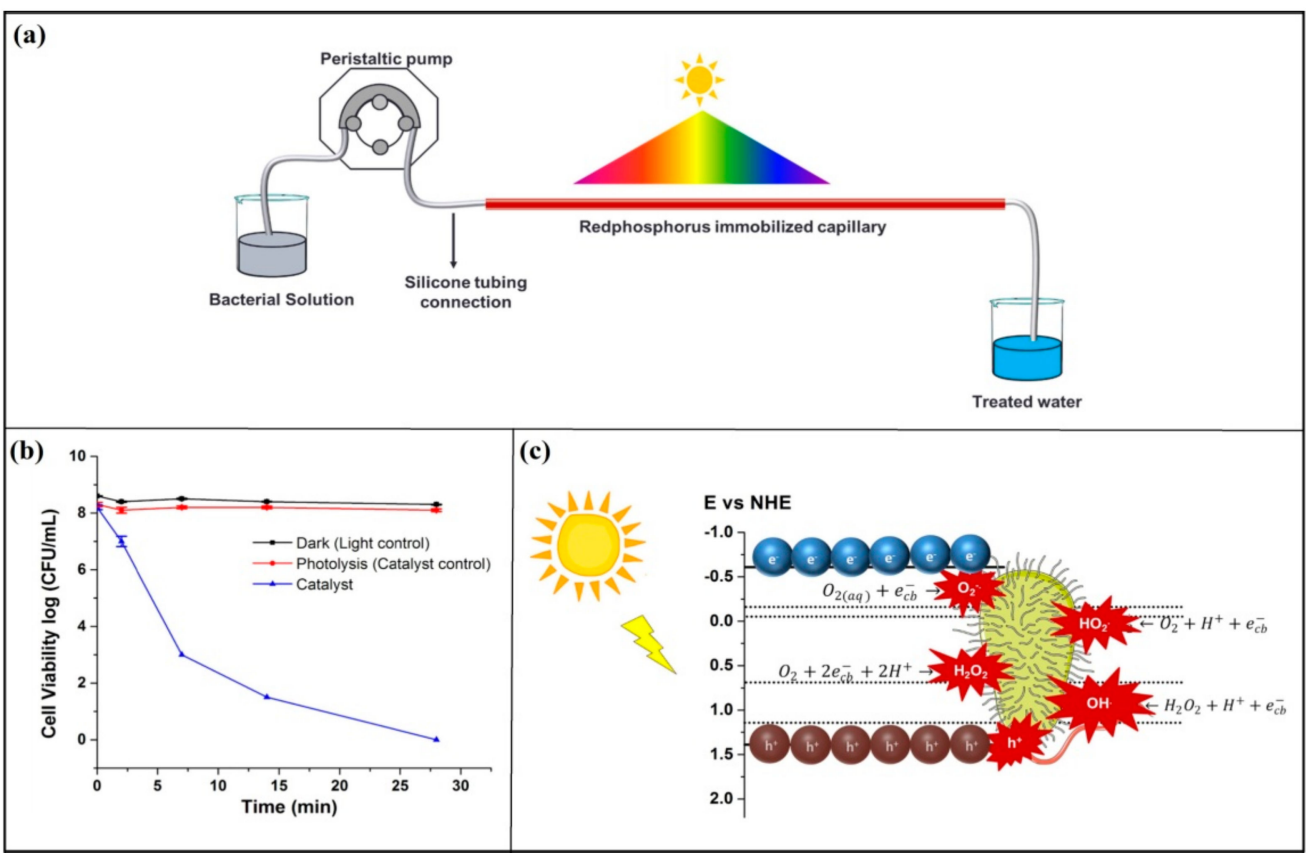

Figure 2. Schematic illustrations of continuous-flow solar photocatalytic disinfection: (a) the overall disinfection process, (b) cell viability, and (c) the mechanism of photocatalytic disinfection. Adapted from Roshith et al. [133].

Numerous designs of SODIS-based continuous flow water purifications systems have recently been investigated, which were based on different solar radiation collectors able to increase water temperature in a continuous flow manner. Domingos et al. [134] developed a continuous-flow SODIS based water disinfection system. This system was composed of a double reflection disk-shaped collector (3.8 and $1.3 \mathrm{~m}$ in diameter). The two solar disks were able to collect and concentrate the radiation and focus it in the aluminum block (the reactor) surrounding the tubular channels for water-flow. The authors were able to achieve $65{ }^{\circ} \mathrm{C}$ water temperatures on average days of solar radiation with a flow rate of $63 \mathrm{~L}$ per hour. However, this temperature was able to inactivate E. coli and other waterborne pathogens. Yildiz [135] stated that the raw water should be filtered to reduce its turbidity and to remove larger particulate matter prior to entering the raw water tank in the continuous flow water purifications systems. Amara et al. [136] fabricated a solar-based continuous flow water purification system by using a $1.3 \mathrm{~m}$ diameter parabolic solar disk. The authors attached the focus of the concentrator to a fluid filled chamber, in addition to using a copper tube (14 mm diameter) to permit fluid-to-fluid heat exchange. By using this system, the authors were able to significantly enhance SODIS performance by increasing 
the temperature of raw water by more than $8.5^{\circ} \mathrm{C}$ (from $52{ }^{\circ} \mathrm{C}$ to more than $60{ }^{\circ} \mathrm{C}$ ) at a flow rate of $1 \mathrm{~L}$ per minute. In a different study, Dobrowsky et al. [137] investigated the water disinfection efficiency of a closed coupled purification system able to significantly reduce the number of water microorganisms. Owing to the metal-based system, the authors were able to significantly enhance the water heating, and reported reduction of E. coli, heterotrophic bacteria, and total coliforms.

\section{Limitations and Challenges of SODIS}

Natural sunlight only contains $5 \%$ of UV, which may not enough to disinfect all the water pathogens even using the photocatalysts. Therefore, most of the solar spectrum is not utilized by these wide band-gap photocatalysts [138]. Another limitation that has been reported with photocatalytic processes is that the particles of the photocatalysts are suspended in the reaction as these processes are normally conducted in the batch mode, forming a slurry of suspended particles of used catalyst, which has to be removed eventually using a post-treatment step such as centrifugation or filtration [139]. Using an external UV source and/or a post-treatment step may significantly impede the cost effectiveness of the SODIS process [140]. Numerous studies aimed to overcome these issues in the past few years, aiming to develop an effective visible light photocatalyst able to ensure that the photocatalysis process worked under normal conditions of SODIS without the need for any external light sources [141,142]. The efficacy and mechanisms of SODIS against E. coli have been extensively studied since the 1980s; other types of pathogens are yet to be studied. In this regard, there are no available predictive approaches for the expected effectiveness of the SODIS process worldwide. Most published studies conducted on batch experiments suggest that the ability of microorganisms to adapt to solar may change the statistics of disinfection potential. Although SODIS is proven to be an effective water treatment process in many low-income communities with promotional strategies, many concerns have been raised recently regarding the conventional SODIS process including the fear of leaching in plastic bottles, cloudy weather and latitude, water turbidity, and community acceptance.

\subsection{Leaching in Plastic Bottles and Potential Adverse Health Effects}

The use of polyethylene terephthalate bottles in the SODIS system in low-income communities raises a public concern of potential chemical release at high temperatures. The use of plastic bottles to expose the water to sunlight, which causes elevation in water temperature, raises health concerns about the potential generation of photoproducts or migration of organic compound from the plastic bottles to treated water, which have been linked with many chronic and genetic disorders [143,144]. A limited number of research studies assessed the adverse health effects and the potential toxicity of consuming the water from SODIS process $[145,146]$. The Ames test was carried out to assess the potential cytotoxicity of the water resulting from the SODIS process $[147,148]$. However, the authors did not report any significant cytotoxicity in the water. The evaluation of advanced oxidative processes (AOP), as most of the studies claim the toxic effect of plastic, was carried out either on higher temperatures than sunlight or the direct evaluation of PET plastic [149]. Westerhoff et al. [150] reported potential health risks from using water after SODIS treatment, due to the plasticizers and carcinogenic compounds that could leach out into the water inside the bottles at a higher temperature. The same authors found exceeded carcinogenic risk levels in SODIS-treated water, which came from the plasticizer di(2ethylhexyl)adipate (DEHA). In a different study, Schmid et al. [151] evaluated the potential transfer of any organic compounds from the PET bottles to treated water during the SODIS process. The authors exposed the bottles to solar power for $17 \mathrm{~h}$ with a total residence time of $48 \mathrm{~h}$ and reported similar values of plasticizer in commercially produced bottled water, revealing a minimum toxicological risk, and a safety factor of 8.5 , for consuming such water. However, other researchers recommended replacing the plastic bottles at least every six months to avoid or at least minimize the effects of their wear and tear. Biopolymeric plastic 
based bottles could be used as a safer option than the petroleum-based ones. A significant number of studies have proven the biocompatibility and safety of using biopolymer-based materials in different applications [152-154]. We believe that biopolymer-based water bottles could be a potential solution to remove the health risk concern of conventional plastic and to minimize plastic pollution and maintain sustainability. Despite the higher leaching potential of biopolymeric bottles compared with the conventional one, their natural base makes them a highly preferable and safer option.

\subsection{Inclement Weather and Latitude}

In the SODIS process, the exposure time of the bottles is mainly dependent on the weather conditions and the location, which may not be available all the time in many countries. Luzi et al. [75] stated that it is recommended to expose the contaminated water for at least $6 \mathrm{~h}$ on sunny days in tropical countries, suggesting leaving the bottles to have a full day in possible cloudy interrupting weather, which is uncommonly found in many countries. However, according to the Swiss Federal Institute, the top population countries around the world, including China, India, Bangladesh, Indonesia, Kenya, and Nigeria, are located in the region considered to be the most suitable regions for SODIS [155]. The weather may not be suitable all the time, but as discussed earlier, using SODIS enhancers could minimize the exposure time and thus increase the rate of water treatment. The use of an external source may increase the costs, but in a large-scale water treatment project, this could be a good option especially in the regions that usually have cloudy interrupting weather.

\subsection{Water Turbidity and Community Acceptance}

Water turbidity is another factor that significantly affects the SODIS process; turbid water by different suspended particles was found to block solar light from reaching the microorganisms within the water, and thus, SODIS is unsuitable in areas with water turbidity of $>30 \mathrm{NTU}$, unless the water was pre-treated or filtered [119]. After treatment, drinking water should have $<1$ NTU, but 5 NTU is satisfactory in many rural water facilities. Successful implementation of a SODIS system requires behavior change as well as alteration to daily life, which is important to reduce health risks among the residents of particular communities. Sommers M. [156] stated that SODIS promotion depends on many factors, which must be taken into serious consideration including risks, attitudes, norms, and ability, which can all significantly impact the efficiency of promotion. Adopting an at-home water treatment systems such as SODIS based is still challenging, as it's associated with poverty as well as lack of resources. However, a community tends to be less likely to adopt it than if it was associated with positive emotions, which is the attitude of many rural areas especially in Africa and southeast Asia [157]. A pre-filter for turbid water and unsuitable weather requires an additional step/s for the water such as pre-treatment filtration and external UV treatment, which some individuals may find to be less user friendly. Furthermore, community acceptance and preconceived notions are further hurdles that the SODIS process faces in many countries. More studies in this regard should be conducted to spread knowledge about the effectiveness and safety of such treatment.

\section{Future Prospective}

Great advances made in recent decades in using SODIS process for water disinfection have proven that this process is an effective and potentially inexpensive water treatment method providing safe drinking water. The modification of the SODIS process using different pre-treatment steps such as coagulant or the use of photocatalysts has significantly enhanced the performance of the SODIS process which has become able to eliminate most of water pathogens and thus reduce the prevalence and even mortality of waterborne diseases. Many communities around the world lacking safe drinking water and still depending on the conventional SODIS may benefit from such modification techniques for better water quality in shorter time. Future generations could witness more utilization 
of solar energy in water treatment applications even in developed countries. The direct conversion of solar energy into electricity using photo-voltaic effects has become priority for many countries as a more sustainable source of electricity than electricity powered by fossil fuels [158]. However, these electric power stations could be developed to treat water and produce energy at the same time. Continuous flow systems for SODIS have been already achieved; a thin network of tubes can be exposed to solar power in these stations to continuously provide the water in addition to the energy in a large-scale base for developed and developing countries. SODIS-based continuous flow systems could significantly increase the productivity of treated water compared with a conventional SODIS process (patch-based approach) using bottles. Traditional SODIS has been used in most cases when sufficient resources of water are not available, especially in rural areas as we mentioned earlier, for affording more expensive treatments approaches such as filtration, chlorination, etc. The future of SODIS will not be only based on bottles, it could be developed to become a faster and more productive continuous flow system. However, in many poor areas all over the world, household-level SODIS could be their available option for many years. Based on our previous discussion, a collective of several studies could be combined together to obtain the desired goal in terms of effectiveness under affordable costs. The modification techniques of SODIS may not be affordable for a household-based system, given that if they cannot afford using the conventional techniques such as filtration and chlorination, it is extremely unlikely that they would be able to afford SODIS additives such as titanium dioxide. Realistically speaking, the SODIS process could someday be applied in the large-scale treatment of drinking water, taking into consideration the benefits of different modification and enhancement techniques that have been applied by researchers. Further economic evaluation studies are highly needed that can address the costs of applying such projects and their potential compared with conventional techniques.

Author Contributions: Conceptualization, A.A.A., E.B.Y. and M.R.; writing-original draft preparation, A.A.A. and E.B.Y.; writing—review and editing, M.I.A., J.L., S.A., A.M.A., M.A.H. and M.R.; supervision, M.I.A., J.L. and M.R.; funding acquisition, M.R. All authors have read and agreed to the published version of the manuscript.

Funding: The authors would like to express their appreciation to Ministry of Higher Education Malaysia for Fundamental Research Grant Scheme with Project Code: FRGS/1/2019/STG07/USM/02/12. The APC was funded by Universiti Sains Malaysia, Malaysia.

Institutional Review Board Statement: Not applicable.

Informed Consent Statement: Not applicable.

Data Availability Statement: Not applicable.

Acknowledgments: The authors would like to express their appreciation to Universiti Sains Malaysia, Malaysia for providing the support and research facilities for this study.

Conflicts of Interest: The authors declare that they have no known competing financial interests or personal relationships that could have appeared to influence the work reported in this paper.

\section{References}

1. Cowie, B.E.; Porley, V.; Robertson, N. Solar disinfection (SODIS) provides a much underexploited opportunity for researchers in photocatalytic water treatment (PWT). ACS Catal. 2020, 10, 11779-11782. [CrossRef]

2. Pichel, N.; Vivar, M.; Fuentes, M. The problem of drinking water access: A review of disinfection technologies with an emphasis on solar treatment methods. Chemosphere 2019, 218, 1014-1030. [CrossRef] [PubMed]

3. McGuigan, K.G.; Conroy, R.M.; Mosler, H.-J.; du Preez, M.; Ubomba-Jaswa, E.; Fernandez-Ibanez, P. Solar water disinfection (SODIS): A review from bench-top to roof-top. J. Hazard. Mater. 2012, 235, 29-46. [CrossRef] [PubMed]

4. Polo-López, M.; Fernández-Ibáñez, P.; Ubomba-Jaswa, E.; Navntoft, C.; García-Fernández, I.; Dunlop, P.; Schmid, M.; Byrne, J.; McGuigan, K.G. Elimination of water pathogens with solar radiation using an automated sequential batch CPC reactor. J. Hazard. Mater. 2011, 196, 16-21. [CrossRef] [PubMed] 
5. Singer, P.C.; Obolensky, A.; Greiner, A. DBPs in chlorinated North Carolina drinking waters. J. Am. Water Work. Assoc. 1995, 87, 83-92. [CrossRef]

6. Nasuhoglu, D.; Isazadeh, S.; Westlund, P.; Neamatallah, S.; Yargeau, V. Chemical, microbial and toxicological assessment of wastewater treatment plant effluents during disinfection by ozonation. Chem. Eng. J. 2018, 346, 466-476. [CrossRef]

7. Aguilar, S.; Rosado, D.; Moreno-Andrés, J.; Cartuche, L.; Cruz, D.; Acevedo-Merino, A.; Nebot, E. Inactivation of a wild isolated Klebsiella pneumoniae by photo-chemical processes: UV-C, UV-C/H2O2 and UV-C/H2O2/Fe3+. Catal. Today 2018, 313, 94-99. [CrossRef]

8. Levchuk, I.; Rueda-Márquez, J.; Suihkonen, S.; Manzano, M.; Sillanpää, M. Application of UVA-LED based photocatalysis for plywood mill wastewater treatment. Sep. Purif. Technol. 2015, 143, 1-5. [CrossRef]

9. Nalwanga, R.; Quilty, B.; Muyanja, C.; Fernandez-Ibañez, P.; McGuigan, K.G. Evaluation of solar disinfection of E. coli under Sub-Saharan field conditions using a 25L borosilicate glass batch reactor fitted with a compound parabolic collector. Sol. Energy 2014, 100, 195-202. [CrossRef]

10. Helali, S.; Polo-López, M.I.; Fernández-Ibáñez, P.; Ohtani, B.; Amano, F.; Malato, S.; Guillard, C. Solar photocatalysis: A green technology for E. coli contaminated water disinfection. Effect of concentration and different types of suspended catalyst. J. Photochem. Photobiol. A Chem. 2014, 276, 31-40. [CrossRef]

11. Byrne, J.A.; Fernandez-Ibanez, P.A.; Dunlop, P.S.; Alrousan, D.; Hamilton, J.W. Photocatalytic enhancement for solar disinfection of water: A review. Int. J. Photoenergy 2011, 2011. [CrossRef]

12. Malato, S.; Fernández-Ibáñez, P.; Maldonado, M.I.; Blanco, J.; Gernjak, W. Decontamination and disinfection of water by solar photocatalysis: Recent overview and trends. Catal. Today 2009, 147, 1-59. [CrossRef]

13. Castro-Alférez, M.; Polo-López, M.I.; Fernández-Ibáñez, P. Intracellular mechanisms of solar water disinfection. Sci. Rep. 2016, 6, $1-10$.

14. García-Gil, Á.; García-Muñoz, R.A.; McGuigan, K.G.; Marugán, J. Solar Water Disinfection to Produce Safe Drinking Water: A Review of Parameters, Enhancements, and Modelling Approaches to Make SODIS Faster and Safer. Molecules 2021, $26,3431$. [CrossRef]

15. Demirel, C.S.U.; Birben, N.C.; Bekbolet, M. A comprehensive review on the use of second generation TiO2 photocatalysts: Microorganism inactivation. Chemosphere 2018, 211, 420-448. [CrossRef]

16. Gomes, J.; Matos, A.; Gmurek, M.; Quinta-Ferreira, R.M.; Martins, R.C. Ozone and photocatalytic processes for pathogens removal from water: A review. Catalysts 2019, 9, 46. [CrossRef]

17. Zhang, Y.; Sivakumar, M.; Yang, S.; Enever, K.; Ramezanianpour, M. Application of solar energy in water treatment processes: A review. Desalination 2018, 428, 116-145. [CrossRef]

18. Chaúque, B.J.M.; Rott, M.B. Solar disinfection (SODIS) technologies as alternative for large-scale public drinking water supply: Advances and challenges. Chemosphere 2021, 281, 130754. [CrossRef] [PubMed]

19. Li, F.; Wichmann, K.; Otterpohl, R. Review of the technological approaches for grey water treatment and reuses. Sci. Total Environ. 2009, 407, 3439-3449. [CrossRef] [PubMed]

20. Chibowski, E.; Szcześ, A. Magnetic water treatment-A review of the latest approaches. Chemosphere 2018, 203, 54-67. [CrossRef] [PubMed]

21. Cho, Y.I.; Lane, J.; Kim, W. Pulsed-power treatment for physical water treatment. Int. Commun. Heat Mass Transf. 2005, 32, 861-871. [CrossRef]

22. Thines, R.; Mubarak, N.; Nizamuddin, S.; Sahu, J.; Abdullah, E.; Ganesan, P. Application potential of carbon nanomaterials in water and wastewater treatment: A review. J. Taiwan Inst. Chem. Eng. 2017, 72, 116-133. [CrossRef]

23. Panahi, Y.; Mellatyar, H.; Farshbaf, M.; Sabet, Z.; Fattahi, T.; Akbarzadehe, A. Biotechnological applications of nanomaterials for air pollution and water/wastewater treatment. Mater. Today Proc. 2018, 5, 15550-15558. [CrossRef]

24. Anjum, M.; Miandad, R.; Waqas, M.; Gehany, F.; Barakat, M. Remediation of wastewater using various nano-materials. Arab. J. Chem. 2019, 12, 4897-4919. [CrossRef]

25. Qian, Y.; Chen, Y.; Hu, Y.; Hanigan, D.; Westerhoff, P.; An, D. Formation and control of C-and N-DBPs during disinfection of filter backwash and sedimentation sludge water in drinking water treatment. Water Res. 2021, 194, 116964. [CrossRef] [PubMed]

26. Meghwal, K.; Agrawal, R.; Kumawat, S.; Jangid, N.K.; Ameta, C. Chemical and Biological Treatment of Dyes. In Impact of Textile Dyes on Public Health and the Environment; IGI Global: Hershey, PA, USA, 2020; pp. 170-204.

27. Salimi, M.; Esrafili, A.; Gholami, M.; Jafari, A.J.; Kalantary, R.R.; Farzadkia, M.; Kermani, M.; Sobhi, H.R. Contaminants of emerging concern: A review of new approach in AOP technologies. Environ. Monit. Assess. 2017, 189, 1-22. [CrossRef] [PubMed]

28. Li, W.; Wu, R.; Duan, J.; Saint, C.P.; van Leeuwen, J. Impact of prechlorination on organophosphorus pesticides during drinking water treatment: Removal and transformation to toxic oxon byproducts. Water Res. 2016, 105, 1-10. [CrossRef]

29. Wang, J.; Zhuan, R. Degradation of antibiotics by advanced oxidation processes: An overview. Sci. Total Environ. 2020, 701, 135023. [CrossRef]

30. Marican, A.; Durán-Lara, E.F. A review on pesticide removal through different processes. Environ. Sci. Pollut. Res. 2018, 25, 2051-2064. [CrossRef]

31. Sciacca, F.; Rengifo-Herrera, J.A.; Wéthé, J.; Pulgarin, C. Dramatic enhancement of solar disinfection (SODIS) of wild Salmonella sp. in PET bottles by H2O2 addition on natural water of Burkina Faso containing dissolved iron. Chemosphere 2010, 78, 1186-1191. [CrossRef] 
32. Downes, A. Researches on the effect of light upon bacteria and other organisms. Proc. R. Soc. Lond. 1877, 26, 488-500.

33. Acra, A.; Karahagopian, Y.; Raffoul, Z.; Dajani, R. Disinfection of oral rehydration solutions by sunlight. Lancet 1980, 2, 1257-1258. [CrossRef]

34. Acra, A.; Jurdi, M.; Mu'Allem, H.; Karahagopian, Y.; Raffoul, Z. Sunlight as disinfectant. Lancet 1989, 333, 280. [CrossRef]

35. Porley, V.; Chatzisymeon, E.; Meikap, B.C.; Ghosal, S.; Robertson, N. Field testing of low-cost titania-based photocatalysts for enhanced solar disinfection (SODIS) in rural India. Environ. Sci. Water Res. Technol. 2020, 6, 809-816. [CrossRef]

36. Rommozzi, E.; Giannakis, S.; Giovannetti, R.; Vione, D.; Pulgarin, C. Detrimental vs. beneficial influence of ions during solar (SODIS) and photo-Fenton disinfection of E. coli in water:(Bi) carbonate, chloride, nitrate and nitrite effects. Appl. Catal. B Environ. 2020, 270, 118877. [CrossRef]

37. Giannakis, S. Analogies and differences among bacterial and viral disinfection by the photo-Fenton process at neutral pH: A mini review. Environ. Sci. Pollut. Res. 2018, 25, 27676-27692. [CrossRef] [PubMed]

38. Mbonimpa, E.G.; Vadheim, B.; Blatchley III, E.R. Continuous-flow solar UVB disinfection reactor for drinking water. Water Res. 2012, 46, 2344-2354. [CrossRef] [PubMed]

39. Vivar, M.; Pichel, N.; Fuentes, M.; López-Vargas, A. Separating the UV and thermal components during real-time solar disinfection experiments: The effect of temperature. Sol. Energy 2017, 146, 334-341. [CrossRef]

40. Valero, P.; Giannakis, S.; Mosteo, R.; Ormad, M.P.; Pulgarin, C. Comparative effect of growth media on the monitoring of E. coli inactivation and regrowth after solar and photo-Fenton treatment. Chem. Eng. J. 2017, 313, 109-120. [CrossRef]

41. Gárcia-Fernández, I.; Polo-López, M.I.; Oller, I.; Fernandez-Ibanez, P. Bacteria and fungi inactivation using Fe3+/sunlight, $\mathrm{H} 2 \mathrm{O} 2$ /sunlight and near neutral photo-Fenton: A comparative study. Appl. Catal. B Environ. 2012, 121, 20-29. [CrossRef]

42. Giannakis, S.; Ruales-Lonfat, C.; Rtimi, S.; Thabet, S.; Cotton, P.; Pulgarin, C. Castles fall from inside: Evidence for dominant internal photo-catalytic mechanisms during treatment of Saccharomyces cerevisiae by photo-Fenton at near-neutral $\mathrm{pH}$. Appl. Catal. B Environ. 2016, 185, 150-162. [CrossRef]

43. Polo, D.; García-Fernández, I.; Fernández-Ibañez, P.; Romalde, J.L. Hepatitis A Virus Disinfection in Water by Solar Photo-Fenton Systems. Food Environ. Virol. 2018, 10, 159-166. [CrossRef]

44. Imlay, J.A. Cellular defenses against superoxide and hydrogen peroxide. Annu. Rev. Biochem. 2008, 77, 755-776. [CrossRef]

45. Gill, L.; Price, C. Preliminary observations of a continuous flow solar disinfection system for a rural community in Kenya. Energy 2010, 35, 4607-4611. [CrossRef]

46. Giannakis, S.; Voumard, M.; Rtimi, S.; Pulgarin, C. Bacterial disinfection by the photo-Fenton process: Extracellular oxidation or intracellular photo-catalysis? Appl. Catal. B Environ. 2018, 227, 285-295. [CrossRef]

47. Berney, M.; Weilenmann, H.-U.; Egli, T. Flow-cytometric study of vital cellular functions in Escherichia coli during solar disinfection (SODIS). Microbiology 2006, 152, 1719-1729. [CrossRef] [PubMed]

48. García-Gil, Á.; Pablos, C.; García-Muñoz, R.A.; McGuigan, K.G.; Marugán, J. Material selection and prediction of solar irradiance in plastic devices for application of solar water disinfection (SODIS) to inactivate viruses, bacteria and protozoa. Sci. Total Environ. 2020, 730, 139126. [CrossRef]

49. Hoerter, J.D.; Arnold, A.A.; Kuczynska, D.A.; Shibuya, A.; Ward, C.S.; Sauer, M.G.; Gizachew, A.; Hotchkiss, T.M.; Fleming, T.J.; Johnson, S. Effects of sublethal UVA irradiation on activity levels of oxidative defense enzymes and protein oxidation in Escherichia coli. J. Photochem. Photobiol. B Biol. 2005, 81, 171-180. [CrossRef] [PubMed]

50. Mahaseth, T.; Kuzminov, A. Potentiation of hydrogen peroxide toxicity: From catalase inhibition to stable DNA-iron complexes. Mutat. Res. Rev. Mutat. Res. 2017, 773, 274-281. [CrossRef]

51. Brudzynski, K.; Abubaker, K.; Miotto, D. Unraveling a mechanism of honey antibacterial action: Polyphenol/H2O2-induced oxidative effect on bacterial cell growth and on DNA degradation. Food Chem. 2012, 133, 329-336. [CrossRef]

52. Gomes, A.; Asad, L.; Felzenszwalb, I.; Leitão, A.; Silva, A.; Guillobel, H.; Asad, N. Does UVB radiation induce SoxS gene expression in Escherichia coli cells? Radiat. Environ. Biophys. 2004, 43, 219-222. [CrossRef]

53. Yahya, E.; Almashgab, A.M.; Abdulsamad, M.A.; Allaq, A.A.; Alqadhi, A.M.; Garatem, F.M.; Aljundi, S.S. Evaluation the Effect of Microwave Radiation on Gram Positive and Negative Bacteria. J. Chem. Nutr. Biochem. 2021, 2, $39-45$.

54. Tyrrell, R.M.; Pourzand, C.A.; Brown, J.; Hejmadi, V.; Kvam, V.; Ryter, S.; Watkin, R. Cellular studies with UVA radiation: A role for iron. Radiat. Prot. Dosim. 2000, 91, 37-39. [CrossRef]

55. Feng, L.; Peillex-Delphe, C.; Lü, C.; Wang, D.; Giannakis, S.; Pulgarin, C. Employing bacterial mutations for the elucidation of photo-Fenton disinfection: Focus on the intracellular and extracellular inactivation mechanisms induced by UVA and H2O2. Water Res. 2020, 182, 116049. [CrossRef] [PubMed]

56. Carratalà, A.; Dionisio Calado, A.; Mattle, M.J.; Meierhofer, R.; Luzi, S.; Kohn, T. Solar disinfection of viruses in polyethylene terephthalate bottles. Appl. Environ. Microbiol. 2016, 82, 279-288. [CrossRef] [PubMed]

57. Sagripanti, J.L.; Lytle, C.D. Estimated inactivation of coronaviruses by solar radiation with special reference to COVID-19. Photochem. Photobiol. 2020, 96, 731-737. [CrossRef] [PubMed]

58. Kohn, T.; Nelson, K.L. Sunlight-mediated inactivation of MS2 coliphage via exogenous singlet oxygen produced by sensitizers in natural waters. Environ. Sci. Technol. 2007, 41, 192-197. [CrossRef]

59. Wegelin, M.; Canonica, S.; Mechsner, K.; Fleischmann, T.; Pesaro, F.; Metzler, A. Solar water disinfection: Scope of the process and analysis of radiation experiments. Aqua 1994, 43, 154-169. 
60. Davies-Colley, R.; Craggs, R.; Park, J.; Sukias, J.; Nagels, J.; Stott, R. Virus removal in a pilot-scale "advanced" pond system as indicated by somatic and F-RNA bacteriophages. Water Sci. Technol. 2005, 51, 107-110. [CrossRef]

61. Safapour, N.; Metcalf, R.H. Enhancement of solar water pasteurization with reflectors. Appl. Environ. Microbiol. 1999, 65, 859-861. [CrossRef] [PubMed]

62. Rijal, G.; Fujioka, R. Use of reflectors to enhance the synergistic effects of solar heating and solar wavelengths to disinfect drinking water sources. Water Sci. Technol. 2004, 48, 481-488. [CrossRef]

63. Harding, A.S.; Schwab, K.J. Using limes and synthetic psoralens to enhance solar disinfection of water (SODIS): A laboratory evaluation with norovirus, Escherichia coli, and MS2. Am. J. Trop. Med. Hyg. 2012, 86, 566-572. [CrossRef]

64. Sichel, C.; De Cara, M.; Tello, J.; Blanco, J.; Fernández-Ibáñez, P. Solar photocatalytic disinfection of agricultural pathogenic fungi: Fusarium species. Appl. Catal. B Environ. 2007, 74, 152-160. [CrossRef]

65. Lonnen, J.; Kilvington, S.; Kehoe, S.; Al-Touati, F.; McGuigan, K. Solar and photocatalytic disinfection of protozoan, fungal and bacterial microbes in drinking water. Water Res. 2005, 39, 877-883. [CrossRef]

66. Heaselgrave, W.; Kilvington, S. The efficacy of simulated solar disinfection (SODIS) against Ascaris, Giardia, Acanthamoeba, Naegleria, Entamoeba and Cryptosporidium. Acta Trop. 2011, 119, 138-143. [CrossRef] [PubMed]

67. McGuigan, K.; Méndez-Hermida, F.; Castro-Hermida, J.; Ares-Mazás, E.; Kehoe, S.; Boyle, M.; Sichel, C.; Fernández-Ibáñez, P.; Meyer, B.; Ramalingham, S. Batch solar disinfection inactivates oocysts of Cryptosporidium parvum and cysts of Giardia muris in drinking water. J. Appl. Microbiol. 2006, 101, 453-463. [CrossRef] [PubMed]

68. Nelson, K.L.; Boehm, A.B.; Davies-Colley, R.J.; Dodd, M.C.; Kohn, T.; Linden, K.G.; Liu, Y.; Maraccini, P.A.; McNeill, K.; Mitch, W.A. Sunlight-mediated inactivation of health-relevant microorganisms in water: A review of mechanisms and modeling approaches. Environ. Sci. Process. Impacts 2018, 20, 1089-1122. [CrossRef] [PubMed]

69. Liu, Y.; Dong, S.; Kuhlenschmidt, M.S.; Kuhlenschmidt, T.B.; Drnevich, J.; Nguyen, T.H. Inactivation mechanisms of Cryptosporidium parvum oocysts by solar ultraviolet irradiation. Environ. Sci. Water Res. Technol. 2015, 1, 188-198. [CrossRef]

70. Castro-Alférez, M.; Polo-López, M.I.; Marugán, J.; Fernández-Ibáñez, P. Mechanistic modeling of UV and mild-heat synergistic effect on solar water disinfection. Chem. Eng. J. 2017, 316, 111-120. [CrossRef]

71. Walker, D.C.; Len, S.-V.; Sheehan, B. Development and evaluation of a reflective solar disinfection pouch for treatment of drinking water. Appl. Environ. Microbiol. 2004, 70, 2545-2550. [CrossRef]

72. Dunlop, P.; Ciavola, M.; Rizzo, L.; Byrne, J. Inactivation and injury assessment of Escherichia coli during solar and photocatalytic disinfection in LDPE bags. Chemosphere 2011, 85, 1160-1166. [CrossRef]

73. Chauque, B.J.M.; Benetti, A.D.; Corcao, G.; Silva, C.E.; Goncalves, R.F.; Rott, M.B. A new continuous-flow solar water disinfection system inactivating cysts of Acanthamoeba castellanii, and bacteria. Photochem. Photobiol. Sci. 2021, 20, 123-137. [CrossRef] [PubMed]

74. Amirsoleimani, A.; Brion, G.M. Solar disinfection of turbid hygiene waters in Lexington, KY, USA. J. Water Health 2021, 19, 642-656. [CrossRef]

75. Luzi, S.; Tobler, M.; Suter, F.; Meierhofer, R. SODIS Manual: Guidance on Solar Water Disinfection; Eawag: Duebendorf, Switzerland, 2016.

76. Arzu, T.; Sevil, Ç. Drinking water disinfection by solar radiation. Environ. Ecol. Res. 2017, 400-408. [CrossRef]

77. Sommer, B.; Marino, A.; Solarte, Y.; Salas, M.; Dierolf, C.; Valiente, C.; Mora, D.; Rechsteiner, R.; Setter, P.; Wirojanagud, W. SODISan emerging water treatment process. Aqua 1997, 46, 127-137.

78. Kehoe, S.; Joyce, T.; Ibrahim, P.; Gillespie, J.; Shahar, R.; McGuigan, K. Effect of agitation, turbidity, aluminium foil reflectors and container volume on the inactivation efficiency of batch-process solar disinfectors. Water Res. 2001, 35, 1061-1065. [CrossRef]

79. Mani, S.K.; Kanjur, R.; Singh, I.S.B.; Reed, R.H. Comparative effectiveness of solar disinfection using small-scale batch reactors with reflective, absorptive and transmissive rear surfaces. Water Res. 2006, 40, 721-727. [CrossRef]

80. Boyle, M.; Sichel, C.; Fernández-Ibáñez, P.; Arias-Quiroz, G.; Iriarte-Puná, M.; Mercado, A.; Ubomba-Jaswa, E.; McGuigan, K. Bactericidal effect of solar water disinfection under real sunlight conditions. Appl. Environ. Microbiol. 2008, 74, $2997-3001$. [CrossRef] [PubMed]

81. Soliman, A.; El-Adawy, A.; Abd El-Aal, A.A.; Elmallawany, M.A.; Nahnoush, R.K.; Abd Eiaghni, A.R.; Negm, M.S.; Mohsen, A. Usefulness of sunlight and artificial UV radiation versus chlorine for the inactivation of Cryptosporidium oocysts: An in vivo animal study. Open Access Maced. J. Med Sci. 2018, 6, 975. [CrossRef]

82. Hijnen, W.; Beerendonk, E.; Medema, G.J. Inactivation credit of UV radiation for viruses, bacteria and protozoan (oo) cysts in water: A review. Water Res. 2006, 40, 3-22. [CrossRef] [PubMed]

83. Fiorentino, A.; Ferro, G.; Alferez, M.C.; Polo-López, M.I.; Fernández-Ibañez, P.; Rizzo, L. Inactivation and regrowth of multidrug resistant bacteria in urban wastewater after disinfection by solar-driven and chlorination processes. J. Photochem. Photobiol. B Biol. 2015, 148, 43-50. [CrossRef] [PubMed]

84. Méndez-Hermida, F.; Castro-Hermida, J.; Ares-Mazas, E.; Kehoe, S.; McGuigan, K.G. Effect of batch-process solar disinfection on survival of Cryptosporidium parvum oocysts in drinking water. Appl. Environ. Microbiol. 2005, 71, 1653-1654. [CrossRef]

85. Chaúque, B.J.; Rott, M.B. Photolysis of sodium chloride and sodium hypochlorite by ultraviolet light inactivates the trophozoites and cysts of Acanthamoeba castellanii in the water matrix. J. Water Health 2021, 19, 190-202. [CrossRef]

86. Zhou, P.; Di Giovanni, G.D.; Meschke, J.S.; Dodd, M.C. Enhanced inactivation of Cryptosporidium parvum oocysts during solar photolysis of free available chlorine. Environ. Sci. Technol. Lett. 2014, 1, 453-458. [CrossRef] 
87. Villegas-Guzman, P.; Giannakis, S.; Rtimi, S.; Grandjean, D.; Bensimon, M.; De Alencastro, L.F.; Torres-Palma, R.; Pulgarin, C. A green solar photo-Fenton process for the elimination of bacteria and micropollutants in municipal wastewater treatment using mineral iron and natural organic acids. Appl. Catal. B Environ. 2017, 219, 538-549. [CrossRef]

88. Giannakis, S.; López, M.I.P.; Spuhler, D.; Pérez, J.A.S.; Ibáñez, P.F.; Pulgarin, C. Solar disinfection is an augmentable, in situgenerated photo-Fenton reaction-Part 1: A review of the mechanisms and the fundamental aspects of the process. Appl. Catal. B Environ. 2016, 199, 199-223. [CrossRef]

89. Shekoohiyan, S.; Rtimi, S.; Moussavi, G.; Giannakis, S.; Pulgarin, C. Enhancing solar disinfection of water in PET bottles by optimized in-situ formation of iron oxide films. From heterogeneous to homogeneous action modes with $\mathrm{H} 2 \mathrm{O} 2$ vs. O2-Part 1: Iron salts as oxide precursors. Chem. Eng. J. 2019, 358, 211-224. [CrossRef]

90. Fagan, R.; McCormack, D.E.; Dionysiou, D.D.; Pillai, S.C. A review of solar and visible light active TiO2 photocatalysis for treating bacteria, cyanotoxins and contaminants of emerging concern. Mater. Sci. Semicond. Process. 2016, 42, 2-14. [CrossRef]

91. Baruah, S.; Pal, S.K.; Dutta, J. Nanostructured zinc oxide for water treatment. Nanosci. Nanotechnol. Asia 2012, 2, 90-102. [CrossRef]

92. Abbasalipourkabir, R.; Moradi, H.; Zarei, S.; Asadi, S.; Salehzadeh, A.; Ghafourikhosroshahi, A.; Mortazavi, M.; Ziamajidi, N. Toxicity of zinc oxide nanoparticles on adult male Wistar rats. Food Chem. Toxicol. 2015, 84, 154-160. [CrossRef]

93. Wong, S.W.; Leung, P.T.; Djurišić, A.; Leung, K.M. Toxicities of nano zinc oxide to five marine organisms: Influences of aggregate size and ion solubility. Anal. Bioanal. Chem. 2010, 396, 609-618. [CrossRef]

94. Sahu, D.; Kannan, G.; Vijayaraghavan, R.; Anand, T.; Khanum, F. Nanosized zinc oxide induces toxicity in human lung cells. Int. Sch. Res. Not. 2013, 2013. [CrossRef]

95. Pasupuleti, S.; Alapati, S.; Ganapathy, S.; Anumolu, G.; Pully, N.R.; Prakhya, B.M. Toxicity of zinc oxide nanoparticles through oral route. Toxicol. Ind. Health 2012, 28, 675-686. [CrossRef]

96. Reddy, M.P.; Venugopal, A.; Subrahmanyam, M. Hydroxyapatite-supported Ag-TiO2 as Escherichia coli disinfection photocatalyst. Water Res. 2007, 41, 379-386. [CrossRef]

97. Loeb, S.K.; Alvarez, P.J.; Brame, J.A.; Cates, E.L.; Choi, W.; Crittenden, J.; Dionysiou, D.D.; Li, Q.; Li-Puma, G.; Quan, X. The technology horizon for photocatalytic water treatment: Sunrise or sunset? Environ. Sci. Technol. 2019, 53, 2937-2947. [CrossRef] [PubMed]

98. Hatamie, A.; Khan, A.; Golabi, M.; Turner, A.P.; Beni, V.; Mak, W.C.; Sadollahkhani, A.; Alnoor, H.; Zargar, B.; Bano, S. Zinc oxide nanostructure-modified textile and its application to biosensing, photocatalysis, and as antibacterial material. Langmuir 2015, 31, 10913-10921. [CrossRef] [PubMed]

99. Yan, B.; Wang, Y.; Jiang, X.; Liu, K.; Guo, L. Flexible photocatalytic composite film of ZnO-microrods/polypyrrole. ACS Appl. Mater. Interfaces 2017, 9, 29113-29119. [CrossRef] [PubMed]

100. Monteagudo, J.M.; Durán, A.; San Martín, I.; Acevedo, A.M. A novel combined solar pasteurizer/TiO2 continuous-flow reactor for decontamination and disinfection of drinking water. Chemosphere 2017, 168, 1447-1456. [CrossRef]

101. Venieri, D.; Fraggedaki, A.; Kostadima, M.; Chatzisymeon, E.; Binas, V.; Zachopoulos, A.; Kiriakidis, G.; Mantzavinos, D. Solar light and metal-doped $\mathrm{TiO} 2$ to eliminate water-transmitted bacterial pathogens: Photocatalyst characterization and disinfection performance. Appl. Catal. B Environ. 2014, 154, 93-101. [CrossRef]

102. Chalew, T.E.A.; Ajmani, G.S.; Huang, H.; Schwab, K.J. Evaluating nanoparticle breakthrough during drinking water treatment. Environ. Health Perspect. 2013, 121, 1161-1166. [CrossRef]

103. Liu, X.; Wang, M.; Zhang, S.; Pan, B. Application potential of carbon nanotubes in water treatment: A review. J. Environ. Sci. 2013, 25, 1263-1280. [CrossRef]

104. Keogh, M.B.; Castro-Alférez, M.; Polo-López, M.; Calderero, I.F.; Al-Eryani, Y.; Joseph-Titus, C.; Sawant, B.; Dhodapkar, R.; Mathur, C.; McGuigan, K.G. Capability of 19-L polycarbonate plastic water cooler containers for efficient solar water disinfection (SODIS): Field case studies in India, Bahrain and Spain. Sol. Energy 2015, 116, 1-11. [CrossRef]

105. Neumann, O.; Feronti, C.; Neumann, A.D.; Dong, A.; Schell, K.; Lu, B.; Kim, E.; Quinn, M.; Thompson, S.; Grady, N. Compact solar autoclave based on steam generation using broadband light-harvesting nanoparticles. Proc. Natl. Acad. Sci. USA 2013, 110, 11677-11681. [CrossRef] [PubMed]

106. Maddigpu, P.R.; Sawant, B.; Wanjari, S.; Goel, M.; Vione, D.; Dhodapkar, R.S.; Rayalu, S. Carbon nanoparticles for solar disinfection of water. J. Hazard. Mater. 2018, 343, 157-165. [CrossRef] [PubMed]

107. Larlee, S.M. Low-Tech Photocatalysts for Solar Water Disinfection (SODIS). Ph.D. Thesis, University of Toronto, Toronto, ON, Canada, 2017.

108. Levchuk, I.; Kralova, M.; Rueda-Márquez, J.J.; Moreno-Andrés, J.; Gutiérrez-Alfaro, S.; Dzik, P.; Parola, S.; Sillanpää, M.; Vahala, R.; Manzano, M.A. Antimicrobial activity of printed composite $\mathrm{TiO} 2 / \mathrm{SiO} 2$ and $\mathrm{TiO} 2 / \mathrm{SiO} 2 / \mathrm{Au}$ thin films under UVA-LED and natural solar radiation. Appl. Catal. B Environ. 2018, 239, 609-618. [CrossRef]

109. Spuhler, D.; Rengifo-Herrera, J.A.; Pulgarin, C. The effect of Fe2+, Fe3+, H2O2 and the photo-Fenton reagent at near neutral pH on the solar disinfection (SODIS) at low temperatures of water containing Escherichia coli K12. Appl. Catal. B Environ. 2010, 96, 126-141. [CrossRef]

110. Achouri, F.; Merlin, C.; Corbel, S.; Alem, H.; Mathieu, L.; Balan, L.; Medjahdi, G.; Ben Said, M.; Ghrabi, A.; Schneider, R. ZnO nanorods with high photocatalytic and antibacterial activity under solar light irradiation. Materials 2018, 11, 2158. [CrossRef] 
111. Méndez-Hermida, F.; Ares-Mazás, E.; McGuigan, K.G.; Boyle, M.; Sichel, C.; Fernández-Ibáñez, P. Disinfection of drinking water contaminated with Cryptosporidium parvum oocysts under natural sunlight and using the photocatalyst TiO2. J. Photochem. Photobiol. B Biol. 2007, 88, 105-111. [CrossRef]

112. Baniamerian, H.; Safavi, M.; Alvarado-Morales, M.; Tsapekos, P.; Angelidaki, I.; Shokrollahzadeh, S. Photocatalytic inactivation of Vibrio fischeri using Fe2O3-TiO2-based nanoparticles. Environ. Res. 2018, 166, 497-506. [CrossRef]

113. Danwittayakul, S.; Songngam, S.; Sukkasi, S. Enhanced solar water disinfection using ZnO supported photocatalysts. Environ. Technol. 2020, 41, 349-356. [CrossRef]

114. Ángel-Hernández, B.; Hernández-Aldana, F.; Osorio, G.P.; Gutiérrez-Arias, J.M. Municipal wastewater treatment by photocatalysis. Rev. Mex. Ing. Química 2021, 20, Cat2438.

115. Núñez-Salas, R.E.; Rodríguez-Chueca, J.; Hernández-Ramírez, A.; Rodríguez, E.; de Lourdes Maya-Treviño, M. Evaluation of B-ZnO on photocatalytic inactivation of Escherichia coli and Enterococcus sp. J. Environ. Chem. Eng. 2021, 9, 104940. [CrossRef]

116. Alvear-Daza, J.J.; García-Barco, A.; Osorio-Vargas, P.; Gutiérrez-Zapata, H.M.; Sanabria, J.; Rengifo-Herrera, J.A. Resistance and induction of viable but non culturable states (VBNC) during inactivation of E. coli and Klebsiella pneumoniae by addition of $\mathrm{H} 2 \mathrm{O} 2$ to natural well water under simulated solar irradiation. Water Res. 2021, 188, 116499. [CrossRef] [PubMed]

117. Meierhofer, R.; Wegelin, M. Solar Water Disinfection: A Guide for the Application of SODIS; Eawag: Dübendorf, Switzerland, 2002.

118. Xia, X.; Lan, S.; Li, X.; Xie, Y.; Liang, Y.; Yan, P.; Chen, Z.; Xing, Y. Characterization and coagulation-flocculation performance of a composite flocculant in high-turbidity drinking water treatment. Chemosphere 2018, 206, 701-708. [CrossRef]

119. Keogh, M.B.; Elmusharaf, K.; Borde, P.; McGuigan, K.G. Evaluation of the natural coagulant Moringa oleifera as a pretreatment for SODIS in contaminated turbid water. Sol. Energy 2017, 158, 448-454. [CrossRef]

120. Lamore, Y.; Beyene, A.; Fekadu, S.; Megersa, M. Solar disinfection potentials of aqua lens, photovoltaic and glass bottle subsequent to plant-based coagulant: For low-cost household water treatment systems. Appl. Water Sci. 2018, 8, 1-9. [CrossRef]

121. Anwar, F.; Rashid, U. Physico-chemical characteristics of Moringa oleifera seeds and seed oil from a wild provenance of Pakistan. Pak. J. Bot 2007, 39, 1443-1453.

122. Arafat, M.; Mohamed, S. Preliminary study on efficacy of leaves, seeds and bark extracts of Moringa oleifera in reducing bacterial load in water. Int. J. Adv. Res. 2013, 1, 124-130.

123. Kristianto, H.; Kurniawan, M.A.; Soetedjo, J.N. Utilization of papaya seeds as natural coagulant for synthetic textile coloring agent wastewater treatment. Int. J. Adv. Sci. Eng. Inf. Technol. 2018, 8, 2071-2077. [CrossRef]

124. Unnisa, S.A.; Bi, S.Z. Carica papaya seeds effectiveness as coagulant and solar disinfection in removal of turbidity and coliforms. Appl. Water Sci. 2018, 8, 1-8. [CrossRef]

125. Freitas, B.L.S.; Sabogal-Paz, L.P. Pretreatment using Opuntia cochenillifera followed by household slow sand filters: Technological alternatives for supplying isolated communities. Environ. Technol. 2019, 2783-2794. [CrossRef]

126. Megersa, M.; Beyene, A.; Ambelu, A.; Triest, L. Coupling extracts of plant coagulants with solar disinfection showed a complete inactivation of faecal coliforms. Clean Soil Air Water 2019, 47, 1700450. [CrossRef]

127. Marobhe, N.J.; Sabai, S.M. Treatment of drinking water for rural households using Moringa seed and solar disinfection. J. Water Sanit. Hyg. Dev. 2021. [CrossRef]

128. Muñoz-Restrepo, M.; Orrego, L.V.; Muñoz-Arango, D.C.; Lozano-Andrade, C.N.; Escobar-Restrepo, M.C.; Arcos-Arango, Y.; Lutgen, P.; Mejia-Ruiz, R. Microbicidal effect of solar radiation (SODIS) combined with Artemisia annua. Dyna 2014, 81, 71-76. [CrossRef]

129. Yu, R.; Zhang, S.; Chen, Z.; Li, C. Isolation and application of predatory Bdellovibrio-and-like organisms for municipal waste sludge biolysis and dewaterability enhancement. Front. Environ. Sci. Eng. 2017, 11, 10. [CrossRef]

130. Xia, D.; Shen, Z.; Huang, G.; Wang, W.; Yu, J.C.; Wong, P.K. Red phosphorus: An earth-abundant elemental photocatalyst for "green" bacterial inactivation under visible light. Environ. Sci. Technol. 2015, 49, 6264-6273. [CrossRef] [PubMed]

131. Ansari, S.A.; Ansari, M.S.; Cho, M.H. Metal free earth abundant elemental red phosphorus: A new class of visible light photocatalyst and photoelectrode materials. Phys. Chem. Chem. Phys. 2016, 18, 3921-3928. [CrossRef]

132. Zhang, Y.; Li, Y.; Ni, D.; Chen, Z.; Wang, X.; Bu, Y.; Ao, J.P. Improvement of BiVO4 photoanode performance during water photo-oxidation using Rh-doped SrTiO3 perovskite as a co-catalyst. Adv. Funct. Mater. 2019, 29, 1902101.

133. Roshith, M.; Pathak, A.; Kumar, A.N.; Anantharaj, G.; Saranyan, V.; Ramasubramanian, S.; Babu, T.S.; Kumar, D.V.R. Continuous flow solar photocatalytic disinfection of E. coli using red phosphorus immobilized capillaries as optofluidic reactors. Appl. Surf. Sci. 2021, 540, 148398. [CrossRef]

134. Domingos, M.; Sanchez, B.; Vieira-da-Motta, O.; Samarão, S.S.; Canela, M.C. A new automated solar disc for water disinfection by pasteurization. Photochem. Photobiol. Sci. 2019, 18, 905-911. [CrossRef]

135. Yildiz, B.S. Performance assessment of modified biosand filter with an extra disinfection layer. J. Water Supply Res. Technol. Aqua 2016, 65, 266-276. [CrossRef]

136. Amara, S.; Baghdadli, T.; Knapp, S.; Nordell, B. Legionella disinfection by solar concentrator system. Renew. Sustain. Energy Rev. 2017, 70, 786-792. [CrossRef]

137. Dobrowsky, P.; Carstens, M.; De Villiers, J.; Cloete, T.; Khan, W. Efficiency of a closed-coupled solar pasteurization system in treating roof harvested rainwater. Sci. Total Environ. 2015, 536, 206-214. [CrossRef] [PubMed] 
138. Kang, X.; Berberidou, C.; Galeckas, A.; Bazioti, C.; Sagstuen, E.; Norby, T.; Poulios, I.; Chatzitakis, A. Visible Light Driven Photocatalytic Decolorization and Disinfection of Water Employing Reduced TiO2 Nanopowders. Catalysts 2021, 11, 228. [CrossRef]

139. Odling, G.; Robertson, N. Bridging the gap between laboratory and application in photocatalytic water purification. Catalysis Sci. Technol. 2019, 9, 533-545. [CrossRef]

140. Li, X.; Lin, H.; Chen, X.; Niu, H.; Liu, J.; Zhang, T.; Qu, F. Dendritic $\alpha$-Fe 2 O 3/TiO 2 nanocomposites with improved visible light photocatalytic activity. Phys. Chem. Chem. Phys. 2016, 18, 9176-9185. [CrossRef] [PubMed]

141. Habibi-Yangjeh, A.; Mousavi, M.; Nakata, K. Boosting visible-light photocatalytic performance of g-C3N4/Fe3O4 anchored with CoMoO4 nanoparticles: Novel magnetically recoverable photocatalysts. J. Photochem. Photobiol. A Chem. 2019, 368, 120-136. [CrossRef]

142. Asadzadeh-Khaneghah, S.; Habibi-Yangjeh, A.; Seifzadeh, D. Graphitic carbon nitride nanosheets coupled with carbon dots and BiOI nanoparticles: Boosting visible-light-driven photocatalytic activity. J. Taiwan Inst. Chem. Eng. 2018, 87, 98-111. [CrossRef]

143. Baiguini, A.; Colletta, S.; Rebella, V. Materials and articles intended to come into contact with food: Evaluation of the rapid alert system for food and feed (RASFF) 2008-2010. Ig. Sanita Pubblica 2011, 67, 293-305.

144. Yahya, E.B.; Alqadhi, A.M. Recent trends in cancer therapy: A review on the current state of gene delivery. Life Sci. 2021, 119087. [CrossRef] [PubMed]

145. Groh, K.J.; Muncke, J. In vitro toxicity testing of food contact materials: State-of-the-art and future challenges. Compr. Rev. Food Sci. Food Saf. 2017, 16, 1123-1150. [CrossRef]

146. Yahya, E.B.; Alfallous, K.A.; Wali, A.; Hameid, S.; Zwaid, H. Growth rate and antibiotic sensitivity effect of some natural and petroleum based materials on Staphylococcus aureus. Int. J. Res. Appl. Sci. Biotechnol. 2020, 7, 7-11. [CrossRef]

147. Monarca, S.; De Fusco, R.; Biscardi, D.; De Feo, V.; Pasquini, R.; Fatigoni, C.; Moretti, M.; Zanardini, A. Studies of migration of potentially genotoxic compounds into water stored in PET bottles. Food Chem. Toxicol. 1994, 32, 783-788. [CrossRef]

148. Ubomba-Jaswa, E.; Fernández-Ibáñez, P.; McGuigan, K.G. A preliminary Ames fluctuation assay assessment of the genotoxicity of drinking water that has been solar disinfected in polyethylene terephthalate (PET) bottles. J. Water Health 2010, 8, 712-719. [CrossRef]

149. Zimmermann, L.; Dierkes, G.; Ternes, T.A.; Völker, C.; Wagner, M. Benchmarking the in vitro toxicity and chemical composition of plastic consumer products. Environ. Sci. Technol. 2019, 53, 11467-11477. [CrossRef] [PubMed]

150. Westerhoff, P.; Prapaipong, P.; Shock, E.; Hillaireau, A. Antimony leaching from polyethylene terephthalate (PET) plastic used for bottled drinking water. Water Res. 2008, 42, 551-556. [CrossRef]

151. Schmid, P.; Kohler, M.; Meierhofer, R.; Luzi, S.; Wegelin, M. Does the reuse of PET bottles during solar water disinfection pose a health risk due to the migration of plasticisers and other chemicals into the water? Water Res. 2008, 42, 5054-5060. [CrossRef]

152. Yahya, E.B.; Jummaat, F.; Amirul, A.; Adnan, A.; Olaiya, N.; Abdullah, C.; Rizal, S.; Mohamad Haafiz, M.; Khalil, H. A review on revolutionary natural biopolymer-based aerogels for antibacterial delivery. Antibiotics 2020, 9, 648. [CrossRef] [PubMed]

153. Yahya, E.B.; Amirul, A.; HPS, A.K.; Olaiya, N.G.; Iqbal, M.O.; Jummaat, F.; H.P.S., A.K.; Adnan, A. Insights into the Role of Biopolymer Aerogel Scaffolds in Tissue Engineering and Regenerative Medicine. Polymers 2021, 13, 1612. [CrossRef]

154. Asyakina, L.; Dolganyuk, V.; Belova, D.; Peral, M.; Dyshlyuk, L. The study of rheological behavior and safety metrics of natural biopolymers. Foods Raw Mater. 2016, 4, 70-78. [CrossRef]

155. Haider, H.; Ali, W.; Haydar, S.; Tesfamariam, S.; Sadiq, R. Modeling exposure period for solar disinfection (SODIS) under varying turbidity and cloud cover conditions. Clean Technol. Environ. Policy 2014, 16, 861-874. [CrossRef]

156. Sommers, M. Limitations of Solar Disinfection (SODIS) Water Treatment in Low-Income Communities. Senior Thesis, Elizabethtown College, Elizabethtown, KY, USA, 2021.

157. Rosa, G.; Clasen, T. Estimating the scope of household water treatment in low-and medium-income countries. Am. J. Trop. Med. Hyg. 2010, 82, 289-300. [CrossRef] [PubMed]

158. Michaels, H.; Benesperi, I.; Freitag, M. Challenges and prospects of ambient hybrid solar cell applications. Chem. Sci. 2021, 12, 5002-5015. [CrossRef] [PubMed] 